Review

\title{
Constructing the ecological sanitation: a review on technology and methods
}

\author{
Ming Hu, Bin Fan*, Hongliang Wang, Bo Qu, Shikun Zhu \\ State Key Laboratory of Environmental Aquatic Chemistry, Research Center for Eco-Environmental Sciences, Chinese Academy of Sciences, Beijing 100085 , \\ China
}

\section{A R T I C L E I N F O}

\section{Article history:}

Received 29 April 2014

Received in revised form

29 February 2016

Accepted 2 March 2016

Available online 15 March 2016

\section{Keywords:}

Ecological sanitation

Evaluation

Wastewater treatment

Sustainability

Rural

\begin{abstract}
A B S T R A C T
Wastewater often contains valuable resources (e.g. organic matter and nutrients). Different from conventional sanitation approaches, the ecological sanitation (Eco-San) system is based on the closure of material flow cycles to recover resources with minimized demands on other resources. The review comprehensively summarized the main components of the Eco-San system (user interface, collection and conveyance, storage and primary treatment, and reuse/disposal), the frequently-used evaluation methods, and the framework of evaluation index system. Some typical practical cases were discussed to demonstrate the managerial implications and popularize the applications of the Eco-San system. The results show that the Eco-San systems are beneficial to resource efficiency, agricultural use of the organic matters and nutrients, and energy recovery although some shortages exist (e.g. high cost, cultural constraints, and complex operation and management). The evaluation methods can help to identify the restriction factors, contributing factors and measures to improve the efficiency of the future Eco-San system. The setting, selection and quantification are three critical steps when using the evaluation indices to complete the evaluation process. This study not only provides the methods for both developing novel Eco-San systems (combinations of the components) and improving the Eco-San systems (evaluation of the combinations) to solve the wastewater problem in rural areas. Considering the challenges or limitations in the Eco-San research, the recommendations for future research may mainly focus on the combination of different components, methods for sustainability assessment, quantification of the evaluation index, and implementation of more real Eco-San cases.
\end{abstract}

๑) 2016 Elsevier Ltd. All rights reserved.

\section{Contents}

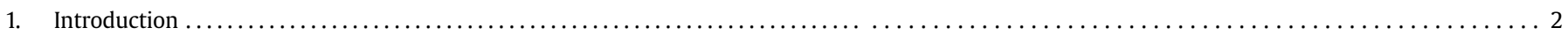

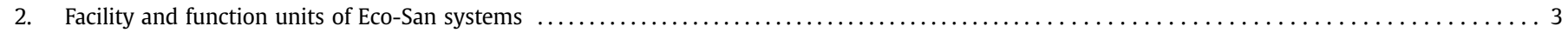

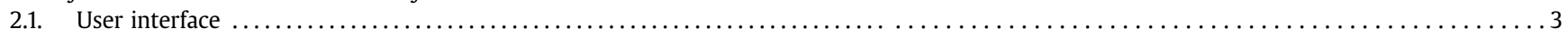

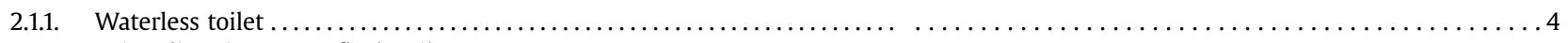

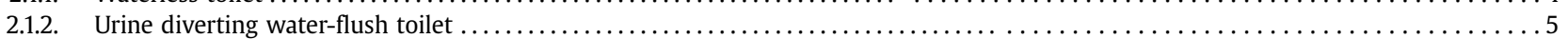

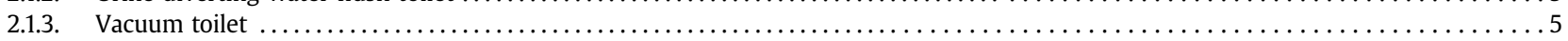

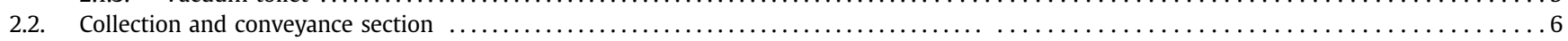

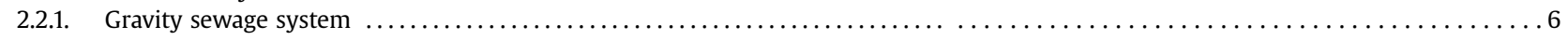

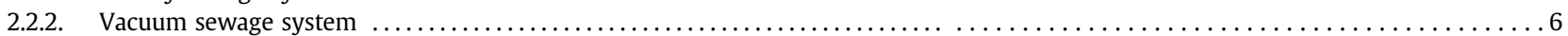

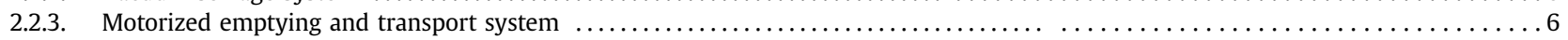

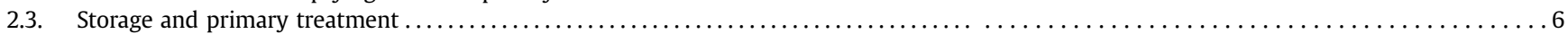

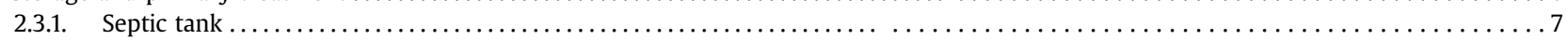

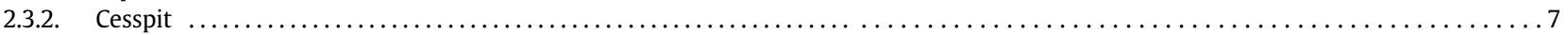

\footnotetext{
* Corresponding author. Tel./fax: +86 1062849142.

E-mail address: fanbin@rcees.ac.cn (B. Fan).
} 


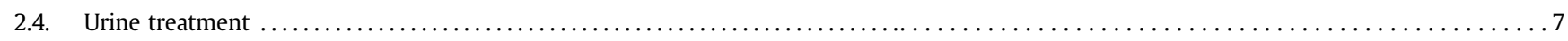

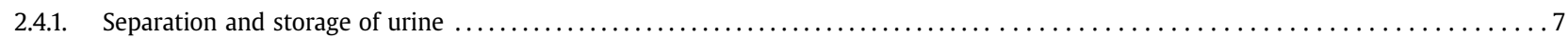

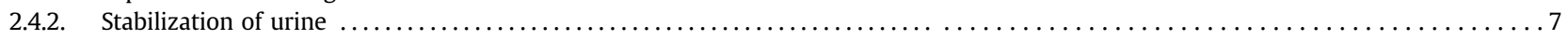

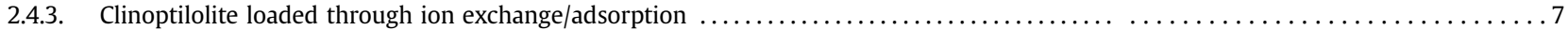

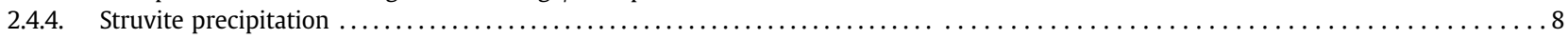

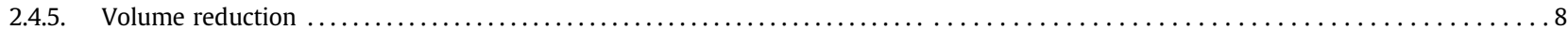

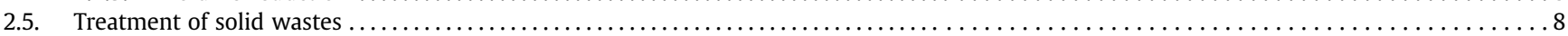

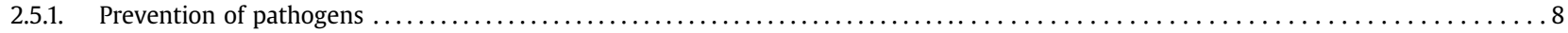

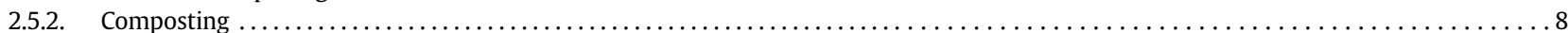

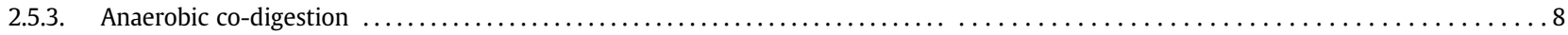

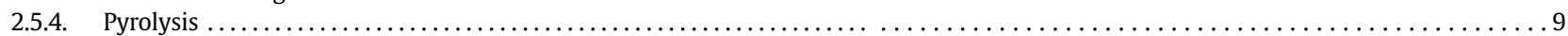

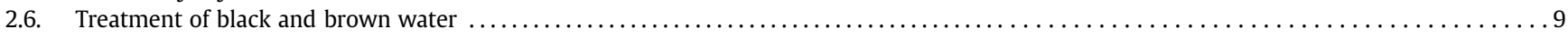

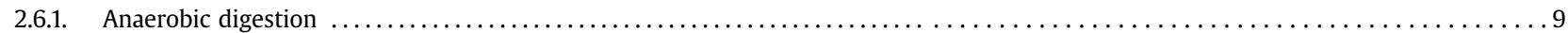

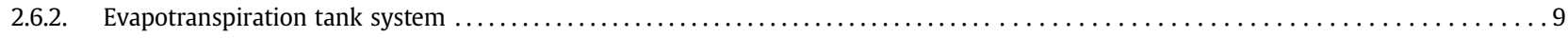

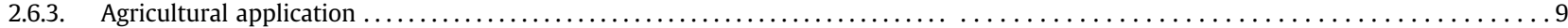

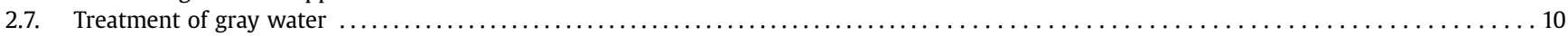

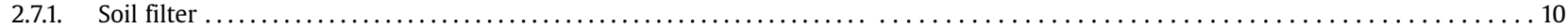

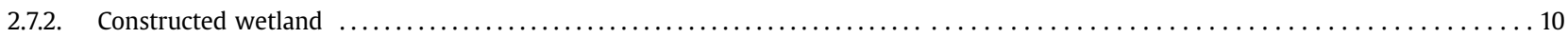

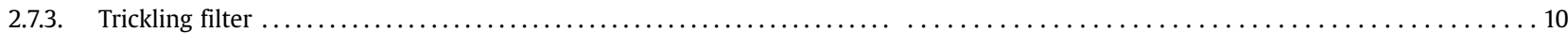

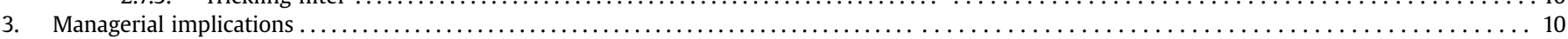

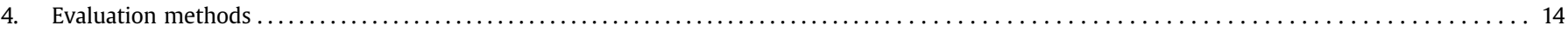

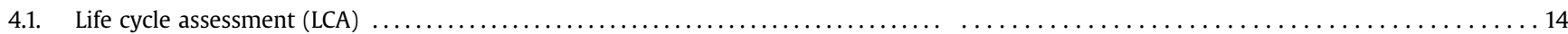

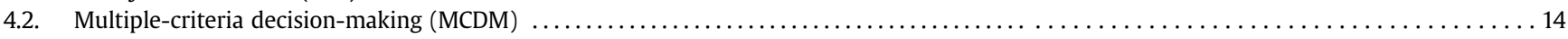

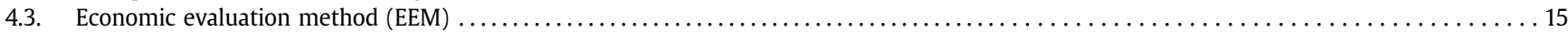

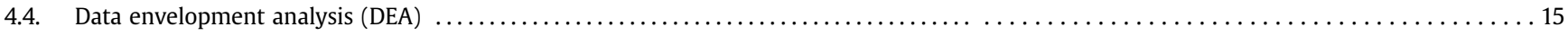

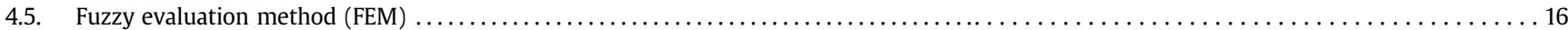

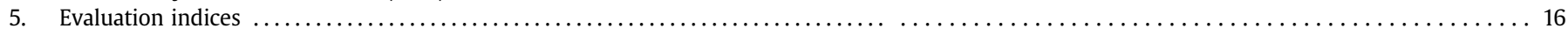

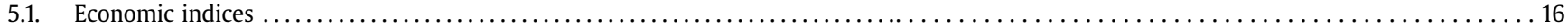

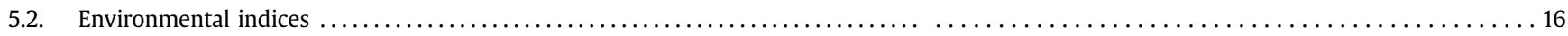

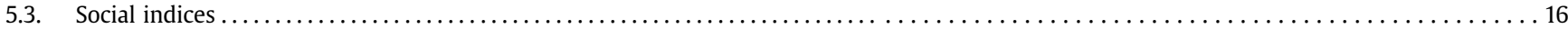

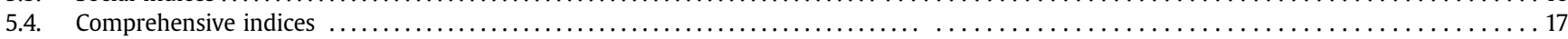

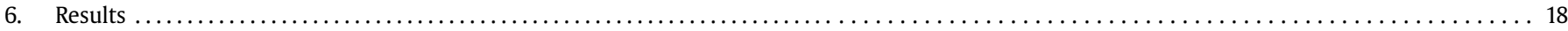

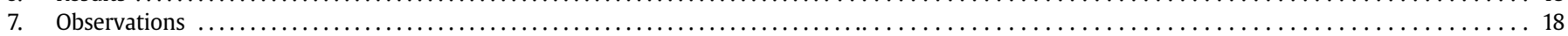

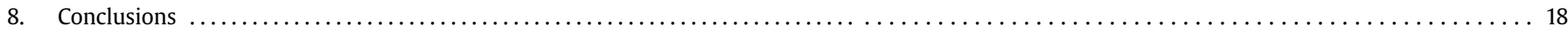

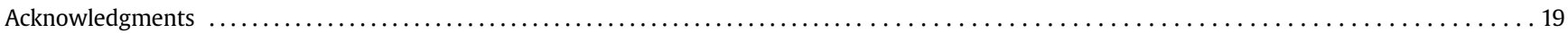

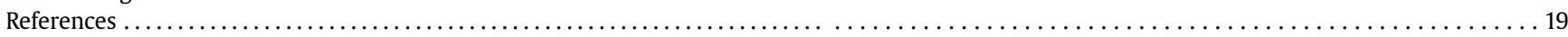

\section{Introduction}

Nearly a half of the global population currently live without sound environment sanitation systems according to modern standard, most of them are in developing countries and many even haven't sanitary toilets. It is a grand challenge to provide environment sanitation systems and services for these people in accordance with affordability, durability, convenience, esthetic design, and effectiveness. Environmental degradation, resources shortfalls and population growth further fuel the vicious circle of poor sanitation. The conventional sanitation (Con-San), which is symbolized by water-flush toilets and mixed-wastewater collection (mainly via a gravitational sewer system with massive water as transportation medium), has so many disadvantages in the terminal treatments of wastewater and wastes, such as requiring complex equipment and expertise to operate and maintain, consuming enormous amounts of energy and resources while still leaving a lot of emissions to ecoenvironments (Sala-Garrido et al., 2012; Mo and Zhang, 2013; Thibodeau et al., 2014), that it is increasingly thought unsustainable in last decades.

In past decades, scientist and engineers have made great efforts, of which the ecological sanitation (Eco-San) is one representative. The term 'Eco-San' appeared in 1990's (Esrey et al., 1998) and quickly got a shot at stardom of the new millennium concepts. The United Nations issued a declaration of 'Eco-San-closing the loop in wastewater management and sanitation' in 2000 (Winblad, 2004). Then in 2001, IWA founded the Eco-San Group affiliating the Sustainable Sanitation Group in Berlin and held the 1st International
Conference on Eco-Sanitation in Nanning, China (Jfnsson, 2001) but the events only continued for other two times (2003 in Lubeck, Germany and 2005 in Durban, the South Africa). In 2003, IWA let 'the Specialist Group on Eco-San' to take over 'the Sustainable Sanitation Group', but it was renamed to 'the Resources Oriented Sanitation Group' in 2007 (IWA, 2007).

The ecological sanitation (Eco-San) system is an alternative approach to realize sustainable sanitation. It is known as the resources-oriented sanitation and based on ecosystem approaches, the closure of material flow cycles, a novel trend of pollution treatment (from sewage disposal to resources reclamation), and a re-conceptualization of sanitation (from a 'drop-flush-forget' mode to environment protection at sources by means of 'drop and reuse' mode) (Haq and Cambridge, 2012; Langergraber and Muellegger, 2005). The Eco-San aims to meet socio-economic requirements, prevent pollution of surface and ground water, sanitize urine and feces, recover nutrient for food production, and save water, energy and resources in a given local context. It is considered more ready and suitable to be applied in rural areas, where the residence is more decentralized and nearer to farmlands than urban.

In last three decades, multiple types of Eco-San systems have been advanced with different user interface, collection and storage, treatment processes, and reuse or recycle of water and nutrients. For example, Guzha et al. (2005) evaluated the effect of using sanitized human excreta on maize production and water productivity, which recommended that ecological toilets should be added to the list of approved sanitation systems; Bdour et al. (2009) discussed several options to achieve sustainability in wastewater 
treatment, and found that organic nutrient cycles and a closed resource loop could provide an approach for managing valuable wastewater resources; Werner et al. (2009) treated the Eco-San system as a new philosophy of dealing with waste and wastewater, which were based on the systematic implementation of the reuse and recycling of nutrients, organics and water as a hygienically safe, closed-loop and holistic alternative; and Magri et al. (2013) evaluated the sanitizing effects of different additives for dry treatment of feces from urine-diverting dry toilets to reduce the pathogenicity of microorganisms carried in fecal material to safe levels so that the Eco-San systems could be effective in providing health and environmental pollution control. However, current studies emphasized mainly on principles, technologies, reuse of nutrients and project examples and less are related to evaluation and selection of the system technology and components of the EcoSan. Evaluation of the Eco-San systems is necessary since it has many important functions in promoting the R\&Ds and applications. It can help to select the suitable Eco-San system among many different styles according to the study area and situation (Malekpour et al., 2013), to compare advantages and disadvantages of the ecological and conventional sanitation systems (Thibodeau et al., 2014), and to improve existing technology or to develop novel sanitation system (Iglesias et al., 2012).

According to the available literature, researches on evaluation of the Eco-San systems can be classified into many types. In terms of wastewater sources, some studies focused on urine application (Guzha et al., 2005), urine treatment (Wilsenach et al., 2007), composting of feces (Magri et al., 2013), and co-composting of feces and kitchen waste (Niwagaba et al., 2009c); in terms of performances, some studies focused on economic feasibility (von Munch and Mayumbelo, 2007), technical feasibility (Lehtoranta et al., 2014), and environmental or social impacts (Lehtoranta et al., 2014; Malekpour et al., 2013). In terms of treatment process, previous studies mainly stressed different styles of toilet (Anand and Apul, 2014), the source-separation collection of the domestic wastewater (Bdour et al., 2009), the treatment technologies of different wastewater (black water, yellow water, brown water and gray water) (Mo and Zhang, 2013), and the acceptability of society, human and managers. The spatial scale used to be selected at one house or building (Benetto et al., 2009), one school (Werner et al., 2009), one village or colony. Additionally, there were few studies on systematic assessment of the whole components of Eco-San (Malisie, 2007; Montangero et al., 2007; Thibodeau et al., 2014).

For the purpose of filling the knowledge gap and facilitating the R\&Ds and applications, the review tries to build a complete framework for evaluating the Eco-San systems. Firstly, system technology of the Eco-San is combed according to the facility and function units of user interface, collection and storage, conveyance, treatment and reuse/disposal, respectively (Tilley et al., 2014). Then the evaluation methods and indices are reviewed. Fig. 1 shows the general framework of the review. The paper is organized as following: Section 2 presents a comprehensive overview of the facility and function units of Eco-San systems, including user interface, collection and conveyance, storage and primary treatment, and reuse/disposal of urine, solid wastes, black and brown water, and gray water. The managerial implications, evaluation methods, evaluation indices and results are presented in Sections $3-6$, respectively. Observations and limitations are presented in Section 7. Section 8 summarizes the conclusions and recommendations for future research.

\section{Facility and function units of Eco-San systems}

The Eco-San aims to reconstruct a sanitation system that imitates the natural ecological processes to digest the human life residues, e.g. excreta and kitchen wastes. Such materials compose the main contamination sources of infections and environmental damage. So the first principle of the Eco-San, either of kind sanitation, is to prevent infections. The second principle of the Eco-San is to digest these materials by ecological way instead of the conventional wastewater and wastes treatment/disposal, so as to construct a more environment and resources sustainable sanitation system. The two principles were well initiated in the by-far researches and practices. However, the third principle is that any innovative sanitation system including Eco-San should be accord with the human beings' desire of better life, which means the EcoSan should be comparable with the Con-San in convenience and esthetic comfort too. This principle is the request of sustainability in human wills, but it was not always stick to in past. The traditional toilets (e.g. pit latrines) are still widely employed in remote areas and undeveloped societies. Although some of the improved traditional toilets contribute to enhancing the elemental hygiene for those vulnerable groups and can be made to accord with the second principle, they do not mean the direction of the Eco-San. So this review doesn't consider these traditional toilets as options of the Eco-San. However, we still agree the traditional toilets and their improved editions is an expedient way to the Eco-San, especially in undeveloped societies.

Generally there are two elementals to construct an Eco-San system for optimizing cost efficiency, resource reuse and waste disposal (Werner et al., 2009). One principle is that sorted collection of flow streams should be conducted according to the different material stream characteristics and specific treatment demands so as to optimize economy and resources reclamation. Another is that unnecessary dilution should be avoided by using waterless or lowflush toilets so as to obtain high concentrations of recyclable resources. In following sections, the system technology of Eco-San which is adaptable to the both principles is discussed according to the facility and function units of user interface, collection and conveyance, storage and primary treatment, and disposal/reuse.

\subsection{User interface}

User interface includes toilet, pedestal, pan, or urinal. Its purpose is to hygienically separate human excreta from human contact so that exposure to fecal contamination can be avoided (Tilley et al., 2014). The style of user interface determines the following direction of technology strategy to realize Eco-San conception, so toilet technology is always the primary topic in the R\&Ds of Eco-San.

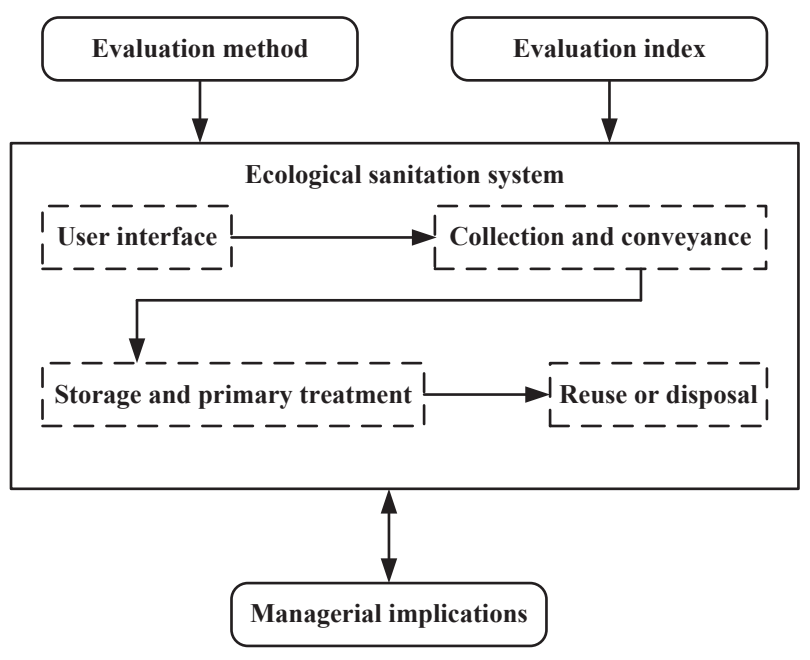

Fig. 1. The general framework of the study. 


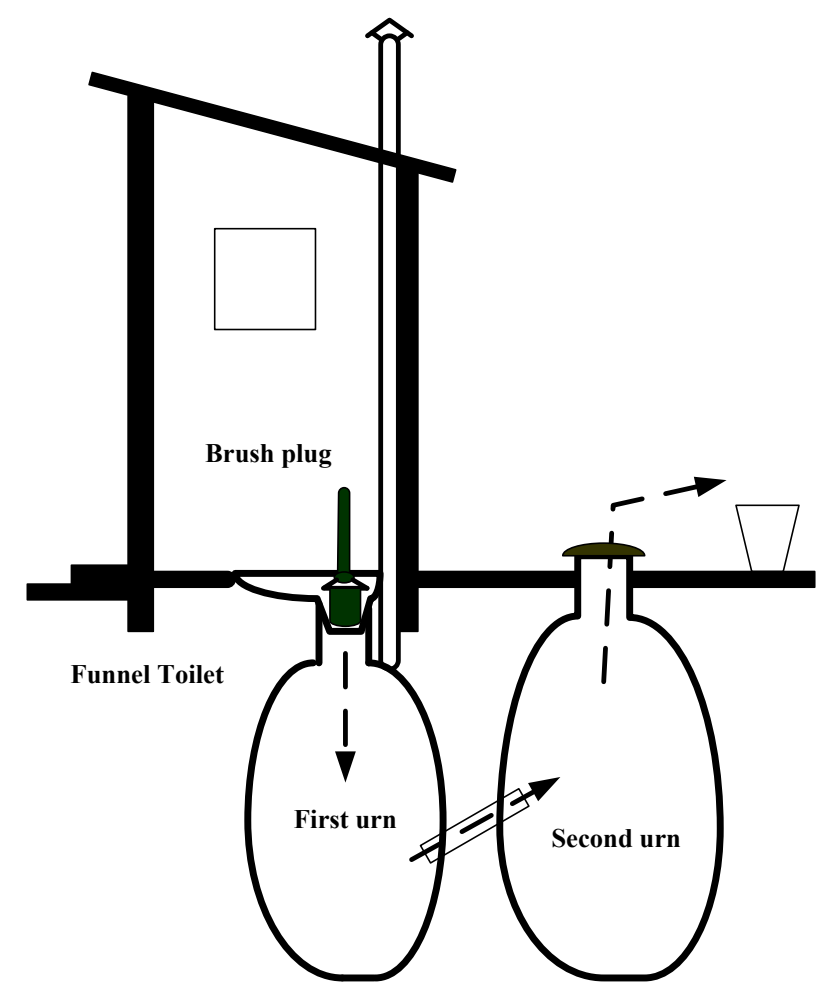

Fig. 2. Dual-urn funnel toilet.

With the development of Eco-San technology, various types of toilets that may comply with the two principles are now available in market, which are typically made from plastic, ceramic, or fiberglass. Some mainstream toilet technologies are discussed in following sections.

\subsubsection{Waterless toilet}

Waterless toilet is a type of toilet unnecessary to use water as conveyance medium, but minor water used for cleaning is permitted. In this sense, waterless toilet also implies it is generally unavailable to a sewer system, and the toilet wastes usually need stay onsite temporarily. Therefore, the crucial challenge of such toilets is how to ensure the sanitation performances of hygiene, convenience and comfort. There are two strategies, one is the basic sanitation that considers mainly to fulfill the elemental hygiene performance, and another is the advanced sanitation that considers to fulfill the synchronous hygiene, convenient and comfort performances according to the modern standard. Generally, the basic sanitation is vulnerable groups oriented, and low cost is preference, so it used to improve traditional toilet, e.g. pit latrine or cesspool. In rural China, four main types of the improved traditional toilet are used: the dual-urn funnel toilet basing on traditional cesspool, the biogas toilet basing on biogas digester, the urine diverting dehydrated toilet, and the alternating dual-pit toilet basing on traditional latrine.

The dual-urn funnel toilet is as shown in Fig. 2. It comprises a funnel acceptor, a front urn that is usually installed indoor, and a back urn that is installed outdoor. A tube connects the two urns and let the fluids in the front urn to pass into the back urn. A little water, generally $3 \mathrm{~L}$ per person/day, is used after discharging. The funnel acceptor should be movable so that slags in the front urn may be cleared away if necessary and it is usually equipped with a handled cover, with which the inlet of the front urn may be covered after discharging. The hydraulic retention time of the front urn cannot be less than 30 days. Materials in the back urn and the cleared slugs are designed to be reused as fertilizer in the context of local agriculture.

Typically, the biogas toilet is installed jointly with livestock, as shown in Fig. 3. Usually, the biogas digester is designed with hydraulic displacement and set underground with an inlet accepting toilet wastes and livestock manures. Other biogenic wastes, e.g. plant waste, may also be acted as filling materials of the biogas reactor. Toilet wastes along with minor cleaning water passes a conduct into the biogas reactor. The biogas is used as household fuel after being desulfurization and deodorization. The effluent digestate flows via an outlet box into a storage tank and then may be used as fertilizer or additive of feedstuff. Fig. 4 shows the general design of the urine diverting dehydrated toilet, similar as what being used in others than China. In the urine diverting toilet, urine is discharged into the front drain and then be collected into a storage tank, which volume should be more than 10 days usage. The collected urine may be act as fertilizer after being diluted 5 times. Feces are dropped down via the back hole into the fecal pit. Cleaning water $(0.1-0.2 \mathrm{~L} /$ time $)$ for the urinal is permitted, but it is

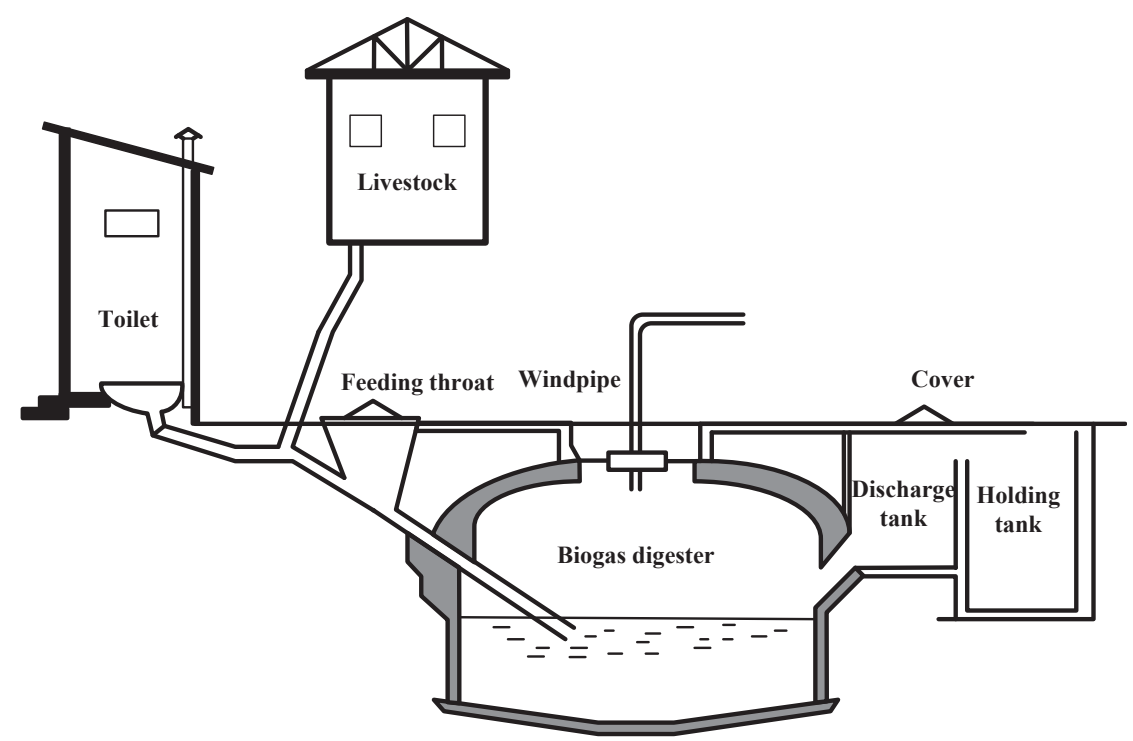

Fig. 3. Three link biogas toilet. 


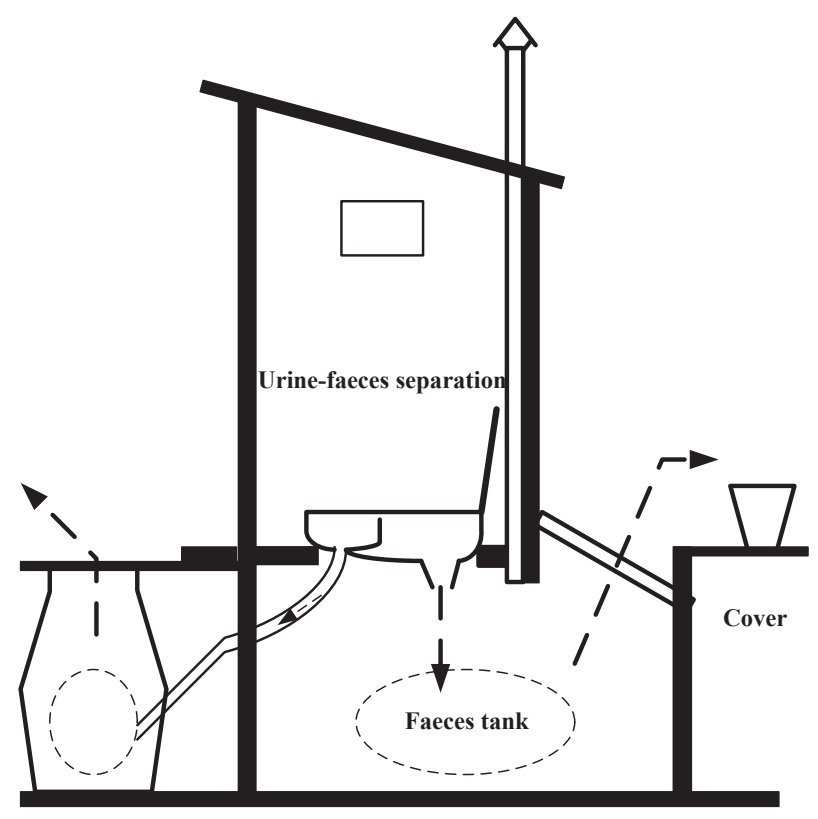

Urine tank

Fig. 4. Urine diverting dehydrated toilet.

prohibited in the back. It is requested to cover the discharged feces every time with powdery materials, e.g. sawdust, plant ashes, and fine sands. The coverings could improve aesthetics and decrease odor of feces. Different coverings result in different time requested for harmlessness, generally at least 3 months for plant ashes and 10 months for sawdust or sands. After then, the excavated materials may be used as fertilizer. Because urine comprises most of the nutrition elements of human excreta and is more readily to be conveyance (liquid) and to be reused (less infectious potential than feces), urine diverting dehydrated toilet has been strongly recommended in others than China. The alternating dual-pit toilet is as shown in Fig. 5. The two pits are employed alternatingly. Urine and feces are both discharged into the pits and covered using soils, which usage had better be enough to absorb the liquids and isolate the excrements from air. When one pit is full, it is sealed up with

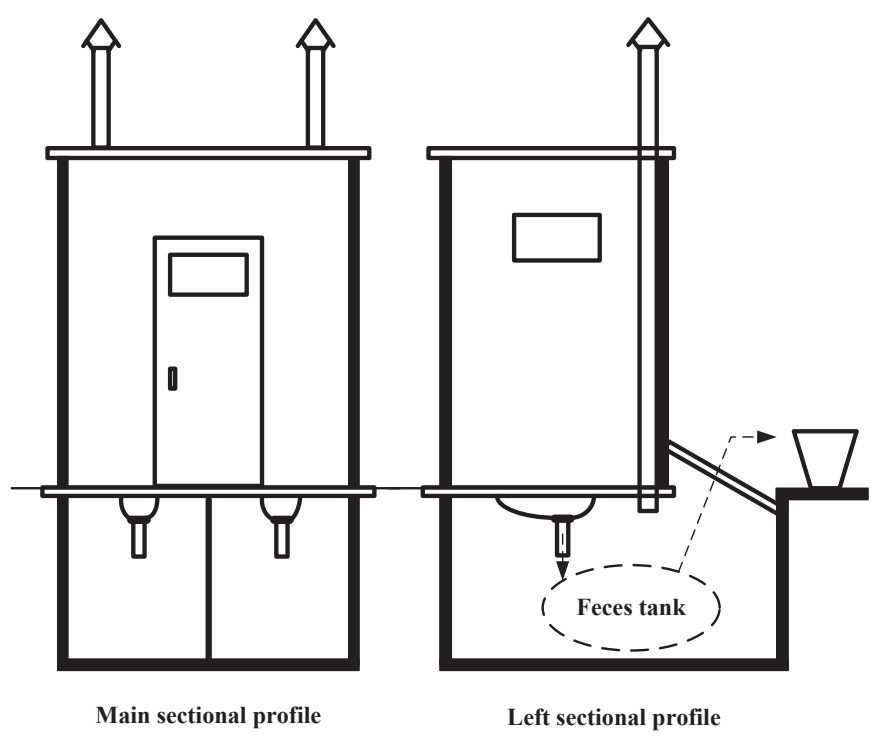

Fig. 5. Alternating dual-pit toilet. soils, and another pit is then put into use. In the sealed pit, materials should be stored for at least 6 months before being excavated as fertilizer.

Some finer designs are employed to improve convenience and comfort performances of the waterless toilet for it to be acceptable by developed groups. Compost toilets are now commercially available with different types of design: being self-contained or centralized, having single or multiple chamber tanks, being waterbased (slurries being treated off-site) or dehydrated (slurries being treated on site), collecting urine separately or collecting urine and feces together, being operated electrically or manually, or being installed in single or multi-storied buildings according to the users' needs (Anand and Apul, 2014). For most waterless toilets, vertical channels should be used to let materials drop down into recipient by gravity. Powdery materials such as fine sands, sawdust, plant ashes and so on are often used in such designs for wrapping excrement, avoiding sticking and facilitating wastes dropping. Foam toilet is a design that uses a mixture of biodegradable soap and water (ca. $0.2 \mathrm{~L} /$ time) to cover the basin of toilet, facilitating user comfort, cleaning, and waste dropping. Foam toilets may have angled channel. However, waterless toilet is usually yet incomparable with the conventional water-flush toilets in convenience and comfort. It is more suitably acted as transitional solutions or be adopted where pipeline water supply is difficult.

\subsubsection{Urine diverting water-flush toilet}

Urine diverting water-flush toilet is designed to separately collect urine so as to reduce load of the wastewater treatment plants while to partially realize resources reclamation. In these toilets, a intersect barrier is usually set to separate toilet basin into front and back drains, urine is discharged through the front drain and then collected and reclaimed as fertilizer, and feces is discharged through the back drain into sewer and then treated together with other wastewater by the conventional way. In urban areas where a complete Con-San system has been built, the conventional toilets can be reformed into urine diverting toilets with a relatively small expense. Urine diverting flush toilets are currently well accepted in some European countries (Lienert and Larsen, 2009).

\subsubsection{Vacuum toilet}

Joel Liljendahl, a Swedish engineer, designed the first vacuum toilet in 1950s. Its first applications were in recreational estates and ships, and later in airplanes and trains. Now vacuum toilets are allowed for different configurations and sizes. Such a vacuum system normally consists of vacuum toilets, pipe work and a vacuum pump station. These toilets may use as less as $0.2 \mathrm{~L}$ water per flush to obtain comparable sanitation performances as the conventional water-flush toilets in hygiene, convenience, and comfort. Additionally because its in-pipe transportation is driven by vacuum suction, installation of the toilets and pipes is little limited by difference of elevation, and the required pipe diameter of the vacuum sewer is about the third of the gravity sewer. Therefore, the total construction cost of the vacuum collection system may be lower than that of the conventional gravity collection system although the former may have more sophisticated toilets and pump station than the latter. Operation of the vacuum collection system is also more economy in water and energy consumptions comparing with the gravity collection system (Fan, 2011). Urine diverting vacuum toilet is available. The shortages of vacuum toilets include more sophisticated equipment and probably more expert maintenance request comparing with conventional water-flush toilets.

Except for the abovementioned three kinds of toilet technologies, innovative toilets are continuously advanced for fulfilling the principles of the Eco-San (Reinvent the Toilet Challenge: China, 
Table 1

The basic information of different toilets (Berger, 2009; Anand and Apul, 2014).

\begin{tabular}{|c|c|c|c|}
\hline Toilet & The volume of flushing (L/flush) & Price (\$ USD) & Web address \\
\hline Composting toilet & $0.17-0.47$ & $1000-4000$ & $\begin{array}{l}\text { http://www.biolet.com/ } \\
\text { http://www.clivusmultrum.com/ }\end{array}$ \\
\hline Urine source separating dry toilet & 1 & $3000-5000$ & http://www.ecotoilets.co.nz/ \\
\hline Urine source separating flush toilet & $2-3$ & $8000-12,000$ & http://www.ecosanres.org \\
\hline Vacuum flush toilet & $0.2-0.5$ & $23,457-396,172$ & http://www.pikkuvihrea.fi/fi \\
\hline Waterless toilet & 1 & $600-1000$ & http://www.ecosanres.org \\
\hline Cistern low-flush toilet & $2-3$ & $1200-1800$ & http://www.ecosanres.org \\
\hline Conventional flushing toilet & $4-6$ & $800-1000$ & http://www.kohler.com.cn/ \\
\hline
\end{tabular}

2013). Additionally as an improvement of the conventional cistern toilets, low-flush cistern toilets are currently popular products in market. Although these toilets are developed mainly for the purpose of saving water, they are potentially applied in the Eco-San. Now the low-flush cistern toilets can lower water consumptions to 3-6 L/flush comparing with 6-9 L/flush of the conventional cistern toilets. However, $3-6 \mathrm{~L} /$ flush is still a little excessive dilution for the following: storage, possible truck conveyance, and resources oriented treatment and reuse. The more dilution of the stream, the less economy is in the following processes. Table 1 shows basic information of different toilets.

\subsection{Collection and conveyance section}

The collection and conveyance section is to deal with the waste products generated at the user interface by removing and/or transporting them to a subsequent treatment offsite. They are either sewer-based technologies or container-based motorized emptying and transport technologies. Generally, the selection of collection and conveyance depends on types and quantities of waste products, distance, accessibility, topography, financial resources and management.

\subsubsection{Gravity sewage system}

The gravity sewage system ensures the collection of the free flowing water and requires no energy input, which is more often found and recommended in areas with high slopes of the land. It is composed of domestic manholes and a pipeline network. Dimensioning of gravity sewers is based on hydraulic and self-cleaning capacities. Typical diameters of gravity sewers outside buildings range from 250 to $1500 \mathrm{~mm}$. In flat areas, this leads to maximum transport distances of $2-3 \mathrm{~km}$ without the installation of pumping stations. To cross either obstacles or upward sloping terrains requires additional pumping stations. Disadvantages of gravity systems are the construction workload required for installing large pipes into the ground, sensitivity towards subsidence and leakage (infiltration and exfiltration), potential formation of hydrogen sulfide, and possible sediment accumulations in the pipes or other parts of the gravity sewer network. As for an Eco-San system, gravity sewer is adaptable to low solid concentration flows such as gray water and yellow water, but it cannot be used to convey high concentration black water and brown water offsite.

\subsubsection{Vacuum sewage system}

Vacuum sewers for human excreta collection and conveyance were firstly introduced in the second half of the 19th century by the Dutch engineer, Liernur (1828-1893). The Liernur system can be considered as a combined solution for the drainage both inside and outside buildings. By the end of the 19th century, the systems were installed in several European cities. However, the system became uneconomic in the early 20th century because of the advent of mineral fertilizer and the dilution of excreta by flushing water.
Vacuum systems also are allowed to collect gray water from shower sinks, washbasins, bath tubes, washing machines, dishwashers and kitchen sinks. In this case, automatic interface units are required to transport water from sanitary appliances by gravity. Once a certain volume is reached, the collection chamber is automatically evacuated towards the vacuum system. Typical diameters are about $40 \mathrm{~mm}$ for vacuum service lines, $50 \mathrm{~mm}$ for vacuum collection lines, and $70 \mathrm{~mm}$ for main collection lines. The vacuum pump can be located within a building complex or at a central location in the neighborhood to serve several buildings. In flat areas, the maximum vacuum sewer branch lengths achievable without additional air intake facilities are roughly $6 \mathrm{~km}$. Since the instant flow velocity may reach a very high speed and sediment accumulation cannot happen in vacuum sewer, it may be used to convey high concentration flow streams of the Eco-San. However for conveying a specific volume of liquids, vacuum sewer may consume 3 times of energy than gravitational elevation, so its economy will be lower when used for dilute flow conveyance. Additionally, operation and maintenance of vacuum sewer is more complex than that of gravitation sewer, but today this question is not a baffle because of the progresses in manufacture, intelligent control and remote information.

\subsubsection{Motorized emptying and transport system}

A motorized emptying and transport system includes a vehicle equipped with both a motorized pump and a storage tank for emptying and transporting fecal sludge, urine and gray water. A vacuum truck is fitted with a pump connected to a hose, which is lowered down into an excreta storage tank or pit, while the waste is pumped up into the holding tank on the vehicle (Tilley et al., 2014). The storage capacity of a vacuum truck is $3-12 \mathrm{~m}^{3}$ based on the requirement. To avoid the clog, garbage and sand are not allowed in the storage tank or pit. When the sludge is too dense to be easily pumped, it is necessary to dilute the sludge with water. On narrow or non-drivable roads or in remote areas, the system would not be employed to collect the excreta because of the feasibility and economy. Therefore, the treatment site must be within reach from the serviced areas.

Comparing with motorized emptying and transport, pipeline transportation is more adaptable to frequent and massive conveyance, but its installation may be uneconomical if the distance is too long and the volume is too small. However, piping is a user friendly way to instantly remove the domestic wastes away from residence, so it is preferred being used for waste collection and conveyance inside residential area. An actual collection and conveyance system of the Eco-San must be an optimized assembly of the different technologies.

\subsection{Storage and primary treatment}

Generally, some user interfaces, such as the toilet with composting chamber, have the self-storage containers. Two main types 
of collection and storage containers (septic tank and cesspit) are frequently used to meet the requirements of temporary storage and primary treatment. Those factors, such as space availability, type and quantity of input products, and user preference, determinate the choice of the containers.

\subsubsection{Septic tank}

As a common facility to store and treat the black/gray water, a septic tank is a watertight chamber made of concrete, fiberglass, PVC or plastic. When the liquid flows through the tank, the heavy parts sink to the bottom and become degraded anaerobically with the scum floating to the top. Considering the low rate of decomposition in the tank, the accumulated sludge and scum should be periodically removed to prevent the overflow. The key factors, such as the number of users, the amount of water used per capita, the desludging frequency and the characteristics of the wastewater, determine the design to ensure the normal and safe operations. For the densely populated areas, the onsite infiltration should not be employed to disperse or transport the effluent originating from septic tank. Otherwise, the ground will become oversaturated and contaminated, which poses serious health risk to people living nearby. Therefore, the septic tank should be connected to conveyances and transported to a subsequent treatment or disposal site.

\subsubsection{Cesspit}

A cesspit can be named as a pit latrine without the aboveground part to protect privacy. It is the most rudimentary form of a dry sanitation system by employing the locally available materials to cover a defecation hole (a pit dug in the ground to collect waste). The volume of the pit should be designed as at least $1 \mathrm{~m}^{3}$. The pit may be functional for 20 or more years without emptying according to the solids excreta cumulative rate of $40-60 \mathrm{~L}$ per person/year. The bottom of the pit should be at least $2 \mathrm{~m}$ above groundwater level to prevent groundwater contamination. The treatment processes in the pit are limited so that pathogen reduction and organic degradation are not significant. Other treatment processes should be proposed to reduce the human health risk and ensure the safe reuse. The cesspit is appropriate for rural and peri-urban areas, especially for the areas where water is in short supply, but not suitable for densely populated areas because of insufficient space for emptying and infiltration.

\subsection{Urine treatment}

Human urine is a liquid waste product of the human body, which is secreted by the kidneys through urination and excreted through the urethra (Karak and Bhattacharyya, 2011). Human urine is the main constituent of yellow water, which has become a significant subject in the field of Eco-San research and practice. Generally, urine contains over $80 \%$ of nitrogen, $50 \%$ of phosphorus, and $50 \%$ of potassium in wastewater (Otterpohl et al., 2004), which is a potential fertilizer because of its high nutrient contents. The use of urine as fertilizer is a practice to serve the idea of sustainability. Urine may be applied onto soil through direct or indirect routes. Despite improvements in plant growth due to direct urine usage are reported, some important issues, such as pathogens, pharmaceuticals, and hormones, need to be considered (Karak and Bhattacharyya, 2011). In indirect routes, ion exchange/adsorption, struvite precipitation, and their combination necessitate some processes before application in order to ensure safety and hygiene.

\subsubsection{Separation and storage of urine}

Separation of human urine at source enhances the sustainability and efficiency of wastewater management since it significantly improves effluent quality and save energy consumption and investment costs of the wastewater treatment plants (Wilsenach and Van Loosdrecht, 2003). In this manner, some technologies, such as the urine diversion toilet, or no mixing toilet, have been designed for better recycling of nutrients. Generally, the urine would be stored for a long time before its application in farms so that the potential health risks from fecal pathogens can be reduced. Three factors, which are storage time, temperature and $\mathrm{pH}$, influence the storage process. For example, losses of nitrogen can be minimized through reducing temperature and avoiding aeration above the liquid surface. High $\mathrm{pH}$, high temperatures, concentrated form of urine and long storage periods are required to attain the safe and hygienic liquid fertilizer. Generally, the storage period of 6 months at $20{ }^{\circ} \mathrm{C}$ or higher is safe for unrestricted use of human urine with respect to pathogens and viable viruses.

\subsubsection{Stabilization of urine}

During separation, storage and transport of urine, several spontaneous processes, such as urea hydrolysis, precipitation or volatilization, may occur and change the urine composition. The urea in urine would be rapidly degraded by urease to ammonium and water, elevating the pH value up to 9 (Udert et al., 2003). The volatilization loss of ammonia has adverse effects on environment and human health. Therefore, stabilization of urine should be necessarily conducted to produce adequate and stable fertilizers so that degradation of organic matter, precipitation processes, and volatilization of $\mathrm{NH}_{3}$ can be prevented. Acidification can achieve the objective. The side effects of acidification are positive with respect to hygiene due to detrimental effects on pathogenic organisms at pH below 4 (Hellström et al., 1999). Low pH values can also have an impact on pharmaceuticals present in the urine. At $\mathrm{pH}=2$, an inactivation level of between $50 \%$ and $95 \%$ could be found for antibiotics and the anti-inflammatory drug diclofenac (Escher et al., 2005). The prevention of urine hydrolysis is much more economical than subsequent neutralization. The neutralization of already hydrolyzed urine requires four times more than preventive acid addition. Ammonia can be easily removed from the liquid phase of urine through air stripping (Basakcilardan-Kabakci et al., 2007) and subsequently be absorbed in sulfuric acid to form ammonium sulfate, a liquid fertilizer. Phosphorus (P) is essential for all living organisms, as it represents the energy currency for organisms at the cell level (Le Corre et al., 2009). Although P is the eleventh most abundant element on the earth, mineral resources of $P$ fertilizers are not abundant in most areas, so it is valuable to reclaim $\mathrm{P}$ nutrition from excreta. Unlike nitrogen, phosphorus contained in human urine has to be transformed into a solid form of struvite precipitation (Harada et al., 2006), which could be used as a fertilizer.

\subsubsection{Clinoptilolite loaded through ion exchange/adsorption}

Clinoptilolite is a typical composition given by the manufacturer (68.3\% $\mathrm{SiO}_{2}, 12.55 \% \mathrm{Al}_{2} \mathrm{O}_{3}, 1.03 \% \mathrm{Fe}_{2} \mathrm{O}_{3}, 0.02 \% \mathrm{TiO}_{2}, 2.33 \% \mathrm{CaO}, 1.09 \%$ $\mathrm{MgO}, 0.88 \% \mathrm{Na}_{2} \mathrm{O}$, and $2.32 \% \mathrm{~K}_{2} \mathrm{O}$ ) (Kocatürk and Baykal, 2012). In the loading process, the $\mathrm{pH}$ of the solutions was adjusted to 7 with $\mathrm{HCl}$, as phosphates in urine would precipitate at $\mathrm{pH}>7$. Preconditioned clinoptilolite was fed in 3.6-cm-diameter columns, which were operated under a $100 \%$ recycled up-flow mode. Clinoptilolite could successfully remove all three nutrients (nitrogen, phosphorus and potassium) with the efficiency of around $90 \%$ for urine concentrations exceeding $50 \%$. Recovery of orthophosphate was more sensitive to urine concentration than that of nitrogen. Nutrient loaded clinoptilolite was as effective as chemical fertilizers. Direct application of urine, either undiluted or diluted, usually produced worse yields than the indirect route. 


\subsubsection{Struvite precipitation}

Through precipitation, the majority of phosphorus in urine can be crystallized into a white, odorless powder called struvite or magnesium ammonium phosphate hexahydrate (MAP, $\left.\mathrm{MgNH}_{4} \mathrm{PO}_{4} \cdot 6 \mathrm{H}_{2} \mathrm{O}\right)$. Struvite is an effective phosphorus fertilizer (Johnston and Richards, 2003), which can be stored and transported easily. Basically, struvite is an orthophosphate, containing magnesium, ammonium, and phosphate in equal molar concentrations. The general formula of minerals of the struvite group is $\mathrm{AMPO}_{4} \cdot 6 \mathrm{H}_{2} \mathrm{O}$, where ' $\mathrm{A}$ ' corresponds to potassium $(\mathrm{K})$ or ammonium ion $\left(\mathrm{NH}_{4}^{+}\right)$and ' $\mathrm{M}$ ' corresponds to cobalt ( $\left.\mathrm{Co}\right)$, magnesium (Mg), or nickel (Ni) (Bassett and Bedwell, 1933). Struvite in the form of a magnesium ammonium phosphate hexahydrate $\left(\mathrm{MgNH}_{4} \mathrm{PO}_{4} \cdot 6 \mathrm{H}_{2} \mathrm{O}\right)$ crystallizes as an orthorhombic structure (i.e., straight prisms with a rectangular base) when human urine is treated with magnesium ion $\left(\mathrm{Mg}^{2+}\right)$. It can then be used as an important slow-release phosphatic fertilizer (Udert et al., 2006). Besides struvite, other minerals, such as epsomite $\left(\mathrm{MgSO}_{4} \cdot 7 \mathrm{H}_{2} \mathrm{O}\right)$, brucite $\left(\mathrm{Mg}(\mathrm{OH})_{2}\right)$ and montgomeryite $\left(\mathrm{Ca}_{4} \mathrm{MgAl}_{4}(-\right.$ $\left.\left.\mathrm{PO}_{4}\right)(\mathrm{OH})_{4} \cdot 12 \mathrm{H}_{2} \mathrm{O}\right)$, may also be formed depending on the amount of other divalent or trivalent metal cations available in urine (Karak and Bhattacharyya, 2011).

\subsubsection{Volume reduction}

Urine contains a lot of water while the nutrient content in urine is small. Therefore, concentrated urine would be beneficial to transportation and storage purposes. Several water extraction techniques have been investigated and developed for long-term space flights (Maurer et al., 2006). Evaporation, such as vapor compression distillation, through thermoelectrically integrated membrane and air evaporation systems, is one of the most straightforward technologies for removing water from urine. And the lyophilization is also one of the feasible approaches to reduce the volume of the urine. If urine is frozen at $-14{ }^{\circ} \mathrm{C}$, approximately $80 \%$ of the nutrients can be concentrated in $25 \%$ of the original volume. However, data from commercial freeze concentrators indicated that an energy consumption of $1100 \mathrm{MJ} / \mathrm{m}^{3}$ is for a fivefold volume reduction. Therefore, evaporation is more efficient with respect to energy efficiency than lyophilization. The freezethaw process will be an option only in cold-climate places with 'cheap' freezing energy. In addition, reverse osmosis is also a feasible technology to reduce the urine volume. In reverse osmosis membranes, the retention of ammonium is better than its uncharged form (ammonia) and the retention performance depends strongly on the $\mathrm{pH}$. At a pressure of 50 bar, a maximum concentration factor of 5 could be achieved, resulting in the following recoveries of nutrients in the retentate: $70 \%$ for ammonium, $73 \%$ for phosphate, and $71 \%$ for potassium. The energy consumption of reverse osmosis depends on operational and technical parameters and energy recovery systems can be installed in large-scale applications (Avlonitis et al., 2003).

\subsection{Treatment of solid wastes}

The solid wastes produced in an Eco-San system include the feces (of dry toilets), kitchen wastes (sorted) and the other abiotic solid wastes (metals, plastics, cloth, paper and etc.). Here mainly discusses the treatment of feces and kitchen wastes. These two materials have similar physical-chemical properties although their compositions are a little different. The other abiotic solid wastes may be treated/disposed like the conventional ways.

\subsubsection{Prevention of pathogens}

The major health risk of fecal matters is of pathogens (Prüss et al., 2002). Ecological and improved traditional sanitation technologies can be effective in providing health safety and environmental pollution control if they can effectively reduce the pathogenicity of microorganisms carried in fecal materials to safe levels (Winker et al., 2009). The success of a reducing pathogens process depends, in general, on both its retention time and the created environment that can inactivate and avoid re-growth of particular organisms (Austin and Cloete, 2008). However, the dynamics of pathogen removal processes are still not clear, which does not guarantee improved sanitation for the respective populations. The thermophilic conditions that could effectively reduce pathogens are reached only with addition of amendments. It is difficult to ensure a homogeneously high temperature and to achieve a uniform reduction in organisms in feces (Niwagaba et al., 2009b), which is essential for full sanitary in that process.

It is common in dry toilets to sprinkle dry substances (e.g. plant ashes, fine sands, oyster shell powders) on top of the feces in order to decrease odor and repel insects. The alkaline ash is conducive to inactivating some pathogens. Oyster shells consist almost completely (99\%) of calcium carbonate and thus has neutral to alkaline characteristics, which can increase and buffer the $\mathrm{pH}$ of feces during storage and also promote desiccation (Magri et al., 2013; Vinneras, 2007). Desiccation, pH and ammonia would affect the result of the inactivation. Oyster shells with urea as an additive is more effective for inactivation of Salmonella typhimurium, since it promoted higher ammonia concentrations in the feces. The use of oyster shells, ash, and urea improved inactivation of Enterococcus faecalis since the mixture also raises $\mathrm{pH}$ in the fecal layer (Magri et al., 2013). A combination of these factors ( $\mathrm{pH}$, desiccation, and ammonia content) shows promising results for sanitizing feces. Maximization of individual effects in a combined process can make it possible to produce a safe additive for urine-diverting dry toilets, especially for those low-level sanitation systems.

\subsubsection{Composting}

Composting is often be used to treat feces and kitchen wastes. Compost toilet is a typical application. When feces and kitchen wastes are composted together, better biodegradation performance can be achieved with an optimum carbon to nitrogen ratio (Niwagaba et al., 2009a). A rapid inactivation of pathogens occurs during composting due to antibiosis, pH-shift, redox-potential, antagonism (hostility among bacterial groups), nutrient deficiencies and exothermic metabolism. The main factors influencing the inactivation of pathogens are temperature, water content, exposure time, and carbon to nitrogen (C:N) ratio of $15: 1$ to $30: 1$ (Martens and Böhm, 2009). Green grass clippings, vegetable scraps, straw, husks and wood shavings, could increase the C:N ratio, provide oxygen to the pile, and help achieve rapid and complete decomposition. Co-composting of excreta with organic waste has potential for application in rural areas to recover nutrients. Composts are used as a soil conditioner to improve agricultural yields (Gaunt and Lehmann, 2008; Steinbeiss et al., 2009). The limitations to application of composting in rural areas include lack of space, capital cost for the facility infrastructure and aeration requirements, and odor problems.

\subsubsection{Anaerobic co-digestion}

Anaerobic co-digestion can be applied to generate biogas while tackle public health and environmental problems associated with poor solid waste and fecal sludge management (Jha et al., 2011). The types of anaerobic digesters as part of the onsite and decentralized sanitation systems approach include continuous wet and dry fixed domes, continuous plug flow and batch dry fixed domes (Münch, 2008). Their operational conditions are: temperature range of $20-35{ }^{\circ} \mathrm{C}$ for mesophilic digestion, total solids content below $20 \%$ for wet systems and $25-50 \%$ for dry systems, and the hydraulic 
retention of 15-30 days (Müller, 2007). The volatile solid loading rate ranges from 1.6 to $4.8 \mathrm{~kg} / \mathrm{m}^{3}$ of active digester volume per day during the complete mix mesophilic anaerobic digestion. The biogas yield rate ranges from 0.25 to $0.95 \mathrm{~m}^{3} / \mathrm{kg}$ volatile solids depending on the feed stock (Appels et al., 2008). The solid wastes can be collected using containers and bins at the household level and transported to digesters using hand carts and small trucks supported by institutional arrangements with private sector involvement. The current trend in research focuses on development of cost-effective technologies for effluent post treatment and recovery of mineral concentrates to make anaerobic co-digestion a core technology for treating mixed solid waste, manure and human excreta (Chen et al., 2008). Some challenges of operating digesters include the highly skilled labor and seeding required. The disadvantages of anaerobic digesters include potential public health risks and negative environment impacts. The pathogen content of the feed stock and the digestate poses risks to human health. There may be risks of fire, explosion and eventual ground water contamination from leachate. Therefore, some measures should be taken in order to successfully implement the anaerobic codigestion.

\subsubsection{Pyrolysis}

The pyrolysis has potential to be applied to resource recovery. The liquid concentrate can be recovered as nitrate-phosphate fertilizer (Aiyuk et al., 2004) and the solid phase subjected to pyrolysis for biochar production at a high temperature of $400{ }^{\circ} \mathrm{C}-700{ }^{\circ} \mathrm{C}$ (Gaskin et al., 2008). As a special type of pyrolysis, hydrothermal carbonization (HTC) is defined as the conversion of biomass into coal under wet conditions and low temperature (around $200{ }^{\circ} \mathrm{C}$ ). Coalification of biomass is a natural chemical process, but takes place on the time scale from some hundreds (for peat) to millions (black coal) of years. Recently, it was discovered that the presence of iron can effectively accelerate HTC, which shortens the process to only a few hours. Since then, HTC has been demonstrated with a vast variety of wet organic wastes in simple and inexpensive experimental set-ups (Titirici et al., 2007). Producing bio-char from fecal sludge or organic solid waste in densely populated areas can have various beneficial effects. These not only provide better hygiene conditions but also increase local supply of cooking fuels (Paraknowitsch et al., 2009). The challenges to application of this technology in rural areas include: the high cost of energy, the explosion risk to the public due to high temperature and pressure, and the market for the bio-char. The net emissions of green-house gases linked to the bio-char cycle are uncertain due to limited experimental data.

\subsection{Treatment of black and brown water}

Black water is the mixture of urine, feces, flush-water, anal cleaning water and or dry cleaning materials (Tilley et al., 2014). The pathogens of feces and nutrients of urine are diluted in the flush-water, which increase the total volume of black water. As produced in less volume than gray water, black water contains more than $95 \%$ of the total nitrogen, $90 \%$ of the total phosphorus and $50 \%$ of the total COD present in domestic wastewater (KujawaRoeleveld et al., 2005). Except for with lower contents of nitrogen and phosphorous, brown water is similar as black water in physical-chemical properties.

\subsubsection{Anaerobic digestion}

Anaerobic digestion is a regular way to treat black or brown water. It employs complex actions of anaerobic microbiology and physical chemistry to have fecal matters decompose, stabilize and separate. Septic tank is the first anaerobic digestion technology invented by human beings. For its simple structure, easy installation and low maintenance, septic tank is often used as a temporal storage and primary treatment facility for black and brown water, and it is promising to act as an onsite terminal treatment if being combined with a suitable farmland application technology. If the retention time is enough ( $>60$ days), septic tank can inactive $90 \%$ of pathogens.

Biogas reactor is one other regular option for black and brown water treatment. It may obtain higher digestion efficiency and reclaim bioenergy comparing with septic tank. However, biogas reactor is more complicated than septic tank in construction and operation. Its operation needs stable source of feeding material, suitable temperature and careful maintenance. Biogas reactor has various styles, such as conventional anaerobic reactors (anaerobic sequencing batch reactors, continuous stirred tank reactors, and anaerobic plug-flow reactors), sludge retention reactors (anaerobic contact reactors, up-flow anaerobic sludge bed reactors, and internal circulation reactors), and anaerobic membrane reactors (anaerobic filter reactors, anaerobic fluidized bed reactors, and expanded granular sludge blankets) (Mao et al., 2015). In order to ensure pathogen prevention, the hydraulic retention time (HRT) of biogas reactors should be at least 15 days in summer and 25 days in winter. If the feeding materials are highly pathogenic, the HRT should be extended to 60 days. The mesophilic biogas reaction is the most common, which the favorable operation temperature ranges from 30 to $38^{\circ} \mathrm{C}$. However, thermophilic reaction by heating operation temperature to $50-57{ }^{\circ} \mathrm{C}$ is more effective in biogas production and pathogens deactivation.

An innovative Sulabh biogas toilet that utilizes biogas digestion was developed in India. The facility consists of a toilet connected to a biogas digester, of which the produced biogas is stored under a fixed dome by hydraulic displacement of the digesting slurry inside the digester (Pathak, 1999). This technology has been implemented for household and public excreta disposal and nutrient recycle in slums (Jha et al., 2011). A similar facility was built for excreta and food residues treatment of a restaurant in Kibera slum, Kenya (Schouten and Mathenge, 2010), and the biogas was used for cooking and heating water.

\subsubsection{Evapotranspiration tank system}

The evapotranspiration tank (TEvap) is an integrated household black or brown water treatment system that combines anaerobic digestion, wetland treatment and plant evapotranspiration (Paulo et al., 2013). A typical design of TEvap is a tank-type facility. Inside the bottom of the tank, an anaerobic compartment is set to receive the black or brown water and allows the solids to settle and to be partially digested. The upperpart of the tank is filled with coarse materials such as tiles, gravel, bricks and rocks, which can act both as filtrating media and biofilm carriers. The top of the tank is covered by a soil layer, on which fast growing and high water consumption plants are planted. When the water rises up into the upper layers, filtration and biological degradation will firstly take place, and then capillary forces, wind and heat, as well as uptake by plants' roots causes elimination of the water by evapotranspiration, while the nutrients are removed by incorporation in the biomass of the plants. Except from few occasions of severe hydraulic overloading, no effluent leaves the system normally. The use of planted systems might also contribute to local production of food, ornamental plants and landscaping, as well as contribute to an improvement of the microclimate in neighborhoods.

\subsubsection{Agricultural application}

It is a long history in East Asia to use the stored feces and urine mixture as fertilizer and this tradition is still in practice in Chinese rural areas. Although currently chemical fertilizers are cheap and 
ready to obtain, some rural villagers persist in using fecal fertilizers to crop cereals, vegetables and fruits for themselves, because the feed cropped by using fecal fertilizers have better taste and are considered healthier. Chinese people used to eat cooked food and drink boiled water, which is helpful to prevent intestinal infectious diseases. However, to directly use fecal fertilizers becomes more and more inapplicable in modern time. Firstly, such a practice has all in all risks of health. Secondly, the traditional application processes of the fecal fertilizers are laborious and unsanitary, and young peoples are unwilling to do such works. It is a future challenge to develop safe, sanitary and convenient application technology of the fecal fertilizers or such things made from black or brown water.

\subsection{Treatment of gray water}

Gray water is domestic wastewater which originates from bathroom, kitchen and laundry use, excluding wastewater from the toilets. It accounts for $65 \%-75 \%$ of the domestic wastewater consumption in peri-urban areas of developing countries where water consumption ranges from $20 \mathrm{~L} /$ ca.d to $30 \mathrm{~L} /$ ca.d (Al-Jayyousi, 2004). Gray water contains many different contaminants, such as suspended solids, pathogens, nutrients, grease, organic micropollutants from household chemicals, and pharmaceuticals that may be present due to urine contamination (Eriksson et al., 2009; Li et al., 2009). Gray water contains a higher level of COD and total suspended solids (TSS) from kitchens than from both bathrooms and laundry (Li et al., 2009). Other sources of gray water have low concentrations of nitrogen and phosphorus. Quantity and quality of gray water vary with living standards, population characteristics (customs, habits) and the sanitation level of service. Gray water is considered only suitable for non-potable use after treatment which depends on the effluent quality and reuse application.

\subsubsection{Soil filter}

Soil filter systems utilize filtration to treat gray water. Filtration involves multiple pollutant removal mechanisms, such as biodegradation, straining, sedimentation, adsorption, nitrification and denitrification. Biodegradation is the primary removal mechanism of organic matter in both solid and liquid phases performed by the active biomass attached to solid surfaces (Rauch and Drewes, 2005). The highest biomass activity occurs in the first $10-30 \mathrm{~cm}$ of the infiltration surface as applied to vertical filtration in both natural and artificial filter systems (Ridderstolpe, 2007). Physical and mechanical straining can also be utilized by using locally available filter media to remove particles larger than the pore space. In filter systems, particulate Kjeldahl nitrogen is also removed by filtration in the upper filter layer and the dissolved part by adsorption onto media particles (Metcalf et al., 1972). Ammonia is removed by adsorption and nitrification-denitrification while phosphorus is removed through chemical precipitation and adsorption (Panuvatvanich et al., 2009). Soil and sand filters can be applied in rural areas because they are robust systems made of locally available materials and can be implemented at the household level.

\subsubsection{Constructed wetland}

Constructed wetlands (CWs) are artificial systems designed to simulate the function of natural wetlands for water quality improvement. CWs have great potential as an optimal alternative for gray water treatment in rural areas because of low cost and energy savings. The three main components of CWs are substrates composed of sand, gravel and other materials in appropriate proportion, a variety of microorganisms and selected pollutionresistant plants. Gray water is purified by the triple (physical, chemical and biological) synergy of the natural ecosystem (Zhang et al., 2012). Other advantages of CWs would be multi-purpose re-use of the high quality effluent, self-remediation and selfadaptation to the surrounding conditions and environment (Brissaud, 2007).

Two types of constructed wetlands systems are commonly designed and used, which are Free Water Surface (FWS) systems and horizontal- or vertical-flow Subsurface Flow (SSF) systems (Zhang et al., 2009). The FWS systems, similar to natural marshes, tend to occupy shallow channels and basins, through which water flows at low velocities above and within the substrate. In the SSF systems, wastewater flows horizontally or vertically through the substrate, which is composed of soil, sand, rock or artificial media. In the horizontal subsurface flow system, the influent flow is under the surface of the bed following a horizontal path until it reaches the outlet zone. In the vertical subsurface flow system, however, the wastewater is fed onto the whole surface area through a distribution system and passes through the filter in a vertical path. As gray water from various sources are generally difficult to treat in a single-stage wetland system, hybrid wetland systems which consist of various types of natural systems staged in series have gained increasing interest in Europe (Vymazal, 2005). For example, to combine ponds and vertical flow CWs or to combine infiltration percolation and horizontal flow CWs have proven to be effective (Brissaud, 2007).

\subsubsection{Trickling filter}

Trickling filter is a fixed-bed, biological reactor that operates under aerobic conditions. Some materials with high specific surface areas, such as rocks, gravel, shredded PVC bottles, or special preformed plastic filter media, have been selected to fill the reactor (Tilley et al., 2014). These materials are an ideal filter media since they are low-cost, light, durable, in a high surface to volume ratio, and allowing air to circulate. High specific surface provides an abundant area for growing biofilms. The pre-treated gray water is trickled over the filter by using a rotating sprinkler. The filter media can be recycled by dosing and exposing to air. Oxygen is depleted within the biomass and the inner layers would be anoxic or anaerobic. Larger pores and primary treatment are essential for preventing clogging and improving air circulation. Adequate air flow is a key factor to ensure sufficient treatment performance and deodorization. The characteristics of gray-water, filter media, temperature and discharge requirements will determine the hydraulic and nutrient loading rates.

\section{Managerial implications}

According to a statics issued in 2012, more than 300 engineering projects were implemented worldwide for practicing and exploring the resources oriented thinking, having benefited about 3 million peoples in about one hundred countries (GIZ, 2012). Most of these projects were done in developing countries with international finance and technology aids, mainly aiming to help vulnerable groups obtain elemental hygiene conditions, and some were done in advanced countries (most in Europe) mainly for demonstrating more sustainable sanitation. The reported project with the highest number of users was executed in Nepal in 1992, which applied biogas digesters for household sanitation of a 686,000 population. Most projects used urine diverting technology both in developing and advanced countries. The general technology routes of these projects were similar: water-saving and source-separation toilets + onsite or offsite treatment + organic fertilizer application, and the differences were mainly in the modernizing levels of toilet related with convenient and comfort performances. Some projects involved attempts of social mobilization, education and 
organization as well as system management. Fig. 6 shows the treatment processes of different projects. Table 2 shows the main components and managerial implications of different projects.

An ecological sanitation project was carried out in a peri-urban area and benefited around 4485 persons in El Alto city, Bolivia. The applied technology is a urine diversion dehydration toilet (UDDT), treatment of gray water at the household level, and collective management of the urine and feces collection, conveyance and reuse. Sawdust was applied to cover the feces after defecation and a small quantity of water after urinating. The collection and transportation of the sub-products was done by professional teams, once a week for urine containers and every 1.5 months for feces containers by van. The fecal matter was composted for 8-9 months with red Californian worms, the urine was stored for 3 months as a treatment to increase the $\mathrm{pH}$ and eliminate pathogens to produce a safe liquid fertilizer. The greywater from the shower and handwashing basin was used to provide water for small wetlands in the backyards of the houses, with ornamental and edible plants.

EI Alto, Bolivia
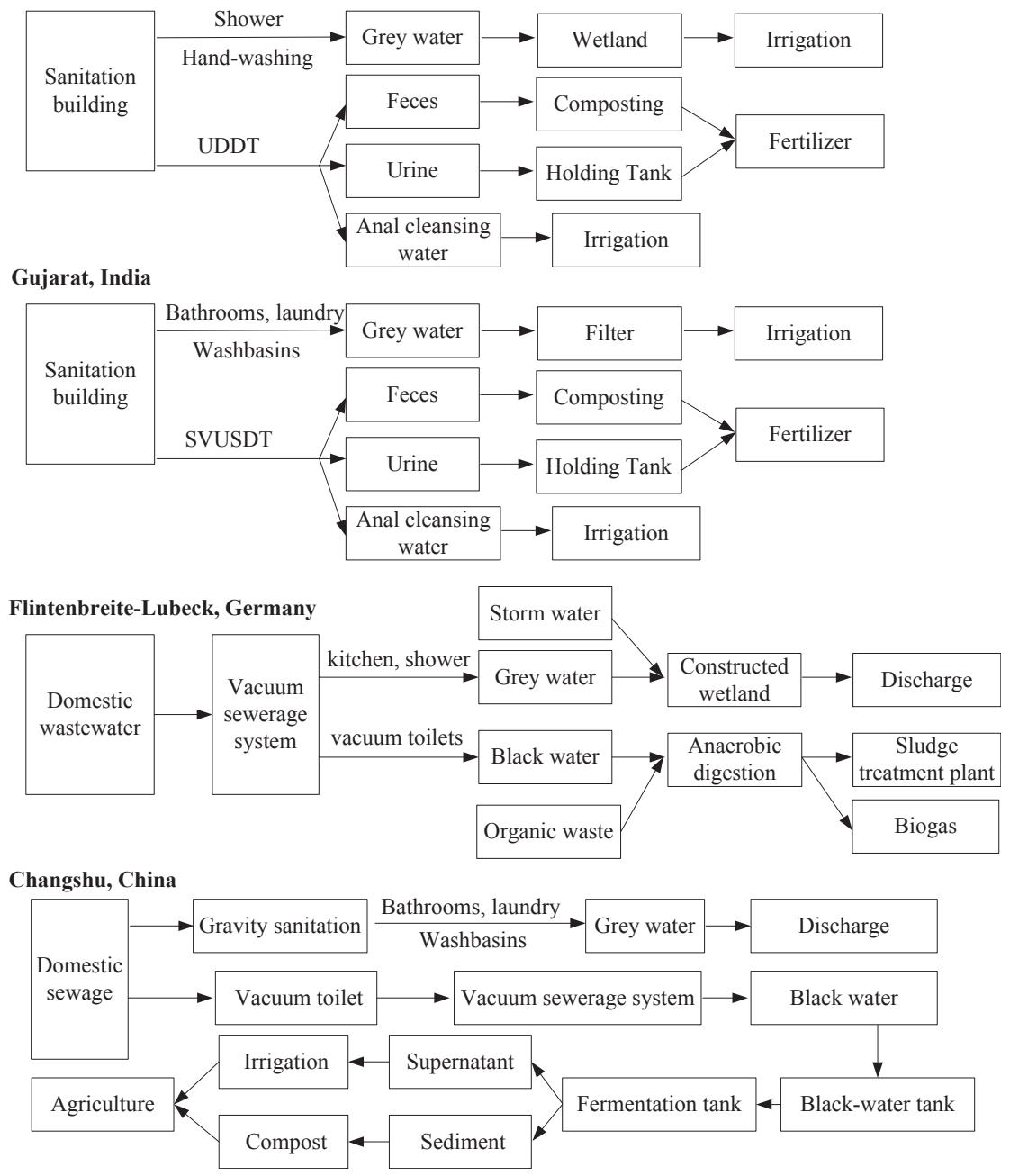

Fig. 6. The treatment processes in different projects.

Table 2

The main components and managerial implications of different projects.

\begin{tabular}{|c|c|c|c|c|c|c|c|}
\hline Study area & Toilet & Sanitation & Urine & Feces & Gray water & Solid waste & Managerial implications \\
\hline Bolivia & UDDT & Gravity & Holding tank & Composting & Wetland & 1 & $\begin{array}{l}\text { Source separation: UDDT + waterless urinal; } \\
\text { Waste treatment: composting; } \\
\text { Resource recycling: no involvement }\end{array}$ \\
\hline India & SVUSDT & Gravity & Holding tank & Composting & Filter & 1 & $\begin{array}{l}\text { Source separation: SVUSDT + waterless urinal; } \\
\text { Waste treatment: natural treatment + composting; } \\
\text { Resource recycling: fertilizer + irrigation }\end{array}$ \\
\hline Germany & VT & Vacuum & Anaerobic diges & stion & Constructed wetland & Anaerobic digestion & $\begin{array}{l}\text { Source separation: vacuum toilet; } \\
\text { Waste treatment: natural treatment + anaerobic digestion; } \\
\text { Resource recycling: biogas }\end{array}$ \\
\hline China & VT & Vacuum & Fermentation & Composting & 1 & 1 & $\begin{array}{l}\text { Source separation: vacuum toilet; } \\
\text { Waste treatment: natural treatment systems; } \\
\text { Resource recycling: fertilizer }\end{array}$ \\
\hline
\end{tabular}


The technology was shown to be effective and lower in cost than centralized sanitation technologies.

In 2005, Navsarjan Trust established a sanitation building including toilets, showers and washing facilities, for a new primary school in rural areas of Gujarat, India. The new school has a total capacity of 210 pupils. Under the conception of sustainability and ecology, the sanitation is designed to provide sanitary appliance to pupils and staff so that the recovery of urine, feces and water for productive purposes is allowed. Two sets of toilets, including eight single-vault-urine-separation dehydration toilets (SVUSDT), are operated in batches to facilitate the harvest of the finished compost. Only four toilets are in use at the same time and receive daily deposits until the dehydration chamber below the squatting slab is "full". Moreover, four waterless urinals for the male pupils and staff members were installed in the toilet to separately collect the urine in a container and reuse it as fertilizers. The gray water from bathrooms, washbasins and the laundry area is treated through vertical flow filters and reused for irrigation in the kitchen garden. The anal cleansing water from the toilets is infiltrated into a subsurface irrigation for ornamental flowers.

A vacuum source-separation system for domestic sanitation was built at a housing estate that had 350 inhabitants in a densely populated rural area of Flintenbreite, Lübeck, Germany in 2002. The settlement was not connected to the public wastewater system. The rainwater of roofs and sealed areas was collected in small gutters and infiltrated to the groundwater via decentralized swales. Vacuum toilet (VT) with low water consumption (0.7-1.2 L/time) was used in households, and the black water (feces and urine) was collected via the vacuum sewer system. The sorted solid kitchen refuse was collected via conventional way to a conditioning plant, where it was crushed and mixed together with the black water. A central anaerobic digester was used to treat the mixed biogenic waste, which was initially treated by thermic disinfection. The liquid residue was stored for a further stabilization and solid residue is composted, and then both of them were used as organic fertilizers. The biogenic wastes treatment plant was still in its startup phase, as the settlement was not yet fully inhabited due to various reasons related to the real estate market. The greywater (wastewater from the kitchen and bathroom) was transported by gravity pipes to several constructed wetlands. The investment for the integrated sanitation system was about EUR 600,000. Investment costs for the sanitation system were approximately $40 \%$ higher than for the common wastewater system, while operation costs were estimated to be $25 \%$ less than in conventional settlements.

The authors ever hosted a rural sanitation project using vacuum source-separation technology in Hehuageng Settlement, Chengtang Village, Guli Town, Changshu, China (Fan, 2011). The project installed 41 household vacuum toilets (pedestal pan) in 23 families (about 100 villagers), which were connected to the vacuum sewer system that included a vacuum pump station and a $750 \mathrm{~m}$ pipe network. The vacuum pump station installed was designed to serve for the whole Hehuageng Settlement, which totally has 55 families, but another half of the settlement failed to be connected into the system for non-technology reasons. The black water (urine and fecal mixture) collected is stored for about two months and then used respectively as liquid fertilizer (by a piping irrigation system) and solid fertilizer (two times per year along with plowing) for the nearby farmlands. The gray water are now drained together with rain water (the designed subsurface filtration system hasn't be installed). The total construction cost covering the vacuum toilets and sewer system was 480,000 RMB (about 73,000 USD), which was approximately equivalent to the planned Con-San system using gravity sewer and SBR wastewater treatment technology. About $70 \%$ of the total construction cost was spent in indoor vacuum toilets installations, including to dismantle the originally installed water-flush toilets and restore the bathroom for the villagers. The system has worked properly since it being completed in the January of 2011, being maintained by a company that also operates the regional rural decentralized wastewater treatment systems of ConSan. The measured water consumption (from April 2011 to March 2013) of the toilets was $0.51 \mathrm{~L} /$ time, and the total electricity consumption of the vacuum pump station was about $1.98 \mathrm{kWh} /$ day. The authors are now planning to collect the kitchen refuses

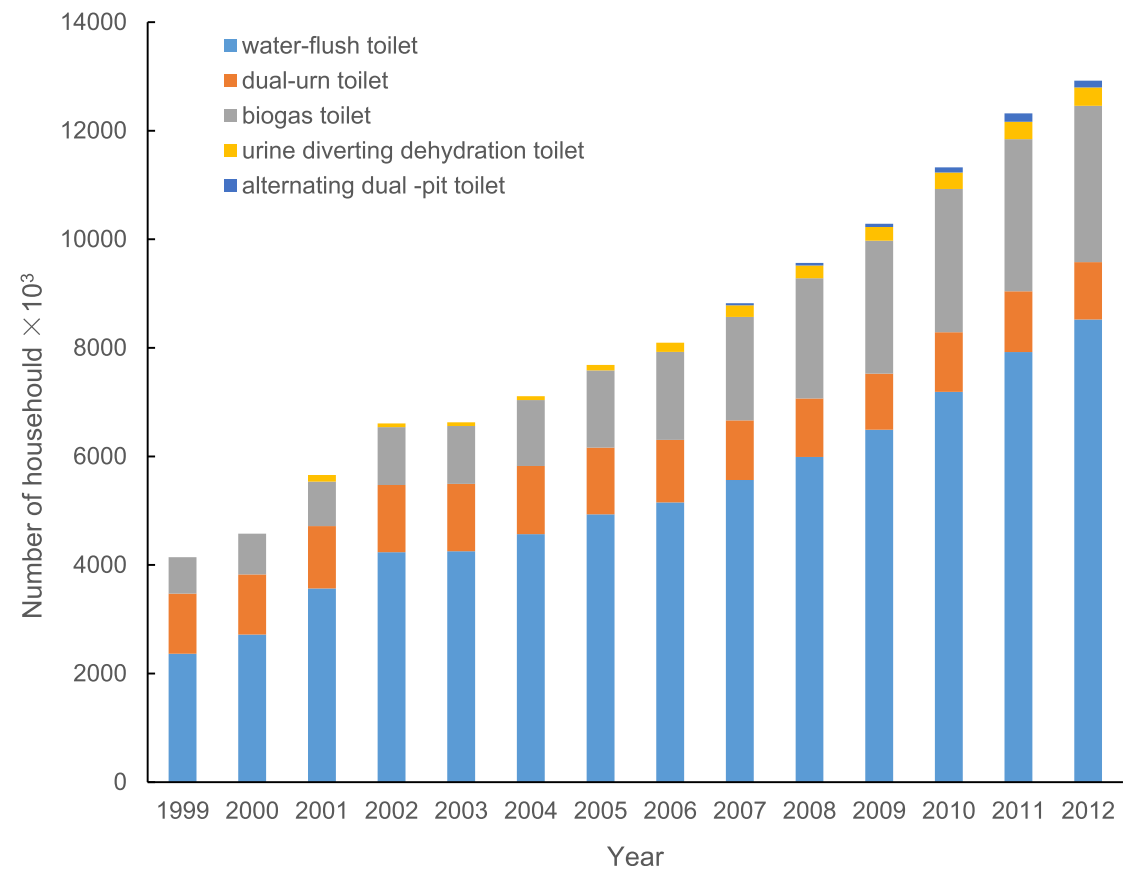

Fig. 7. Yearly numbers of different toilets installed in rural China in 1999-2012. 
(including solids and liquids) of the 23 families into the vacuum system by a home appliance with grinder. If so, the total cost of the domestic solid waste collection, transportation and disposal would be cut down $80 \%$, and the pollutant concentrations of gray water would be largely decreased, furtherly raising the system technological-economic performances.

The largest sanitation project related with the resources oriented thinking is launched and prompted by the Chinese central and local governments, though its original intention is to improve the poor rural sanitation conditions. This project can be traced back to 1950 's, when the central government launched 'the Movement of Patriotic Sanitation' and the governments at all levels set a 'Patriotic Sanitation Committee' that was responsible for promotion, organization and implementation of the rural hygiene. In 1990 's, the 'Toilet Revolution' began to run fast, and the sanitary toilet owning rate in rural areas was lifted up from 39.8\% in 1993 to $75 \%$ in 1999 . And in 2004 , rural toilet reformation was officially listed in the inventory of the transfer payment from central government budget. From then on, six types of toilets are subsidized by the central government and local governments (generally 50\%:50\%), among which four types of waterless toilets are dual-urn toilet, biogas toilet, urine diverting dehydration toilet, and alternating dual-pit toilet. Fig. 7 presents the yearly number of the different household toilet installed in Chinese rural areas from 1999 to 2012 (China Health Statistical Yearbooks, 1999-2012). It can be seen that the biogas toilet and the dual-urn funnel toilet is the two most applied waterless toilets. From 1999 to 2012, number of the biogas toilet kept on rising while that of the dual urn funnel toilet is relatively steady and even appeared to decrease in recently. Because of the biogas toilet being considered not only sanitation but also with additional benefits such as fuel reclamation and livestock pollution control, it gained an additional subsidy from the Agricultural Ministry, which just in 2006-2010 had subsidized 21.2 billion RMB (about 3.3 billion USD) for rural biogas. However since biogas digester had special requests on raw material supply and professional operation, about half of the biogas toilet cannot yet produce biogas after 3 years later (Hou et al., 2012). As a general trend, the Chinese rural peoples are preferred water-flush toilets, as shown in Fig. 7.

Although these projects more or less testified the concepts and technological feasibility of the resources oriented thinking and achieved much in practice as well as in academia, the resources oriented sanitation cannot yet really challenge Con-San in technology. The questions are in variety, but the first lies in idea. By far, most of the regarding R\&Ds and engineering practices are facing to undeveloped peoples, trying to develop some low-cost solutions to those absolute poverties yet not enjoying the elemental hygiene. Although this is a great respecting charity, it entangles with social problems and cannot be solved by only technology. The technologies developed and applied facing to this situation have hardly any attraction to those in normal society, especially where economy is improved. Similarly, just to pursuit the global sustainability by abating the human aspires for nice sanitation conditions either dooms unpromising. The Erdos Eco-town Project which was launched in Haozhaokui Community, Dongsheng District, Inner Mongolia Autonomous Region of China in 2003 is a profound lesson (Winblad et al., 2004). This project installed centralized urine diverting dry toilet system to serve for 3000 residents (832 apartments in 42 buildings with $4-5$ stories and one building with 2 stories). The sanitation system consisted of: 832 urine diversion dry toilets, 832 low-flush urinals, 832 faeces collection bins in the basements (with ventilation systems), 22 urine tanks in the basements, one greywater treatment plant, and one composting plant. The urine and feces flow streams started at the urine diversion dry toilets and waterless urinals which diverted the liquid and solid excreta from each other. A "turning bowl feces receptacle" in the dry toilet was connected to a vertical pipe chute with a diameter of $280 \mathrm{~mm}$ so that after use the feces dropped vertically down into the basement where they were collected in $120 \mathrm{~L}$ bins. $60-80 \mathrm{ml}$ of sawdust was manually added to the feces after each toilet use in order to keep the contents of the bins dry and reduce odor. The feces collection bins were connected to a ventilation system that was meant to vent odor from the bins to vent pipes on the roof. The pipes from the urine section in the toilet and the urinals were led to the urine tanks where the urine was collected and stored for 3 months. A tanker truck was used to empty the urine tanks and the stored urine could be applied as a fertilizer to local agriculture. The greywater in the system came from the kitchen sinks, showers and bathtubs. It flowed into a separate pipe system to an on-site greywater treatment plant. The plant used primary sedimentation, anaerobic treatment, activated sludge and aerobic bio-film treatment, secondary sedimentation and a holding pond to treat the water. The bins were collected with a truck by the maintenance workers and taken to the on-site indoor thermal composting plant where the feces were processed into an organic fertilizer product for agricultural application. The treatment measures within the system, i.e. urine storage and thermal composting at $50-60^{\circ} \mathrm{C}$, all resulted in a reduction of pathogens. Although maintenance personnel contacts with fecal matters are unavoidable during collection and transportation, no incidences of disease were reported throughout the project period. Objectively to speak, this project well implemented the resources oriented thinking, and it tried to use certain advanced technology for fulfilling a high-level sanitation. However, the project was failed at last. Because of the residents rigorously protesting, all the dry toilets had to be removed and substituted by water-flushed toilets. This project has severe negative effects on advocating and practicing the resources oriented thinking in China till today. In this project, finance was not a problem. Superficially the residents were lack of patience to endure a little comfortlessness (e.g. odor) and inconvenience (e.g. excessive toilet fault), but the elementals lay in that people's desire of good sanitation conditions, which have been set at a fairly high-

Table 3

The comparative environmental damage of Eco-San and Con-San.

\begin{tabular}{|c|c|c|c|c|c|c|}
\hline \multirow[t]{2}{*}{ Index } & \multicolumn{2}{|l|}{$A^{a}$} & \multicolumn{2}{|l|}{$\mathrm{B}^{\mathrm{b}}$} & \multicolumn{2}{|l|}{$\mathrm{C}^{\mathrm{c}}$} \\
\hline & Eco-San & Con-San & Eco-San & Con-San & Eco-San & Con-San \\
\hline Climate change & $98.98 \%$ & $100 \%$ & $75 \%$ & $100 \%$ & $84.28 \%$ & $100 \%$ \\
\hline Resources & $98.99 \%$ & $100 \%$ & $80 \%$ & $100 \%$ & $66.03 \%$ & $100 \%$ \\
\hline Human health & $106.52 \%$ & $100 \%$ & $90 \%$ & $100 \%$ & $39.13 \%$ & $100 \%$ \\
\hline Ecosystem quality & $97.96 \%$ & $100 \%$ & $95 \%$ & $100 \%$ & $62.14 \%$ & $100 \%$ \\
\hline
\end{tabular}

Note: The higher the score, the higher the potential environmental impact.

a Benetto et al. (2009).

b Remy (2010).

c Thibodeau et al. (2014). The score of this literature was the result from the exclusion of the process of recycling. 
level by Con-San. Anyhow the resources oriented sanitation would accord with this desire. Otherwise, it cannot be accepted by the contemporary main society.

\section{Evaluation methods}

The above mentioned components are the basic elements of Eco-San, and their combinations would form many different EcoSan systems with different environmental impacts on soil, water and atmosphere. The comparison between the Eco-San and the Con-San systems can be found in existing literature. Malisie (2007) built a pilot-scale source-separation domestic wastewater system to study the potential of nutrient recovery and reuse. It was found that up to $86 \%$ and $12 \%$ of nitrogen, $21 \%$ and $68 \%$ of phosphorous, and $69 \%$ and $20 \%$ of potassium from urine and fecal matters respectively could be recovered by using urine diverting toilets; Benetto et al. (2009) compared an Eco-San system and conventional systems at an office building with practical data. Compared with conventional systems, Eco-San could reduce the contribution to ecosystem quality damage by more than $60 \%$. However, Eco-San may lead to higher damages on resources and human health and higher impact on climate change; Haq and Cambridge (2012) thought that conventional sanitation systems had high capital, operational and maintenance costs. However, agricultural use of human excreta from Eco-San systems provided a strong financial incentive as it reduced expenditure on waste management and chemical fertilizers; Thibodeau et al. (2014) compared the environmental performances of ecological sanitation systems based on black water source-separation (BWS) and conventional sanitation system (CSS) in terms of environmental damage. And the results showed that BWS generated higher impact scores than CSS, which were $100 \%, 89 \%, 24 \%$ and $25 \%$ more in terms of the human health, ecosystem quality, and climate change and resources indices, respectively. According to these literatures, these advantages and disadvantages existing in the Eco-San system and conventional sanitation system could be found, which is beneficial to improving their evaluation. Table 3 shows comparative environmental damage of Eco-San and ConSan. For each index, the relative score of Eco-San is presented proportionally to Con-San score (100\%). Higher scores represent higher potential environmental impacts.

According to Section 2, the components of the Eco-San include user interface, collection and conveyance, storage and primary treatment, and reuse/disposal. Each component has many different sub-styles for selection. Therefore, the challenge to rural environment management lies in the selection of the most suitable type of Eco-San. Several tools can be employed to evaluate and select the elements. The information provided by these tools may be integrated in a multi-criteria decision analysis (MCDA) framework that facilitates decision making with diverse opinions from a variety of stakeholders (Sala-Garrido et al., 2011). Many factors are involved in the decision-making process while data are available only for a few of these criteria. Many candidate evaluation methods can be used for evaluating particular types of ecological sanitation.

\subsection{Life cycle assessment (LCA)}

Life cycle assessment (LCA) is one of the most accepted evaluation tools in the framework of sustainability, as it enables to estimate the cumulative environmental impacts of a product or a process from 'cradle to grave' (Pasqualino et al., 2009). It may provide an accurate picture of the true environmental trade-offs when selecting technology or process among different options. It can also assist to identify opportunities for improving the environmental performances of a certain product or process, to inform decision-makers of industry, government or nongovernment organization in strategic planning, priority setting, product or processes design or redesign, to select relevant indices for environmental impact assessment. LCA addresses the potential environmental impacts throughout a product's life cycle from raw material acquisition, production, use, and end-of-life treatment, disposal or recycling (i.e. cradle-to-grave). Generally, an LCA consists four phases. Phase I is to scope the system boundary and level of details, which depends on the subject and the intended use of the study. The depth and the breadth of LCA can differ considerably depending on its particular goal. Phase II is to make and analyze a life cycle inventory of the input/output data with regard to the system being studied. Phase III is to make a life cycle impact assessment, aiming to provide additional information to help assess a product system's LCI results for better understanding their environmental significance. The final phase is life cycle interpretation, in which the results of life cycle inventory or a life cycle impact assessment, or both, are summarized and discussed as a basis for conclusions, recommendations and decision-making in accordance with the goal and scope definition.

\subsection{Multiple-criteria decision-making (MCDM)}

Multiple-criteria decision-making (MCDM) has widespread application to environmental decision-making problems, such as environmental planning, selection of soil cleaning technology, landfill site selection, and ranking different contaminated areas according to their need for environmental management. The MCDM methods use a structured and logical approach to select the best strategy or alternative for continuous or discrete decisionmaking problems encountered (Kalbar et al., 2012b). The MCDM has two categories: multiple-attribute decision-making (MADM) and multiple-objective decision-making (MODM) (Zanakis et al., 1998). Generally, the MADM methods can handle the discrete decision problems, which involve a finite set of well-defined alternatives. These alternatives have to be evaluated and prioritized using a set of multiple conflicting attributes (Zhou et al., 2006). The MODM can handle the continuous decision problems involving an infinite number of feasible alternatives (Huang et al., 2011). The MODM methods are multiple-objective mathematical programming models in which a set of conflicting objectives are optimized and subjected to a set of defined constraints.

One of the most commonly used MADM methods is the weighted summation (Howard, 1991). In the weighted summation, the criteria is represented on a commensurate scale (usually $0-1$, where 1 represents the best performance), multiplied by weights, and then summed to estimate the overall utility or score. The more complex utility function can be used to capture the preferences of decision makers in the form of various attributes. Multi-attribute utility theory (MAUT), another commonly used MADM method, aims to produce a complete ranking of alternatives. Huber (1974) and Keeney (1975) developed various models to apply MAUT. Most of the MAUT models use additive and multiplicative forms of utility measurement. The simple multi-attribute rating technique (SMART) is the simplest form of MAUT. Another set of MADM methods are based on an outranking approach, where the decision maker can express a strict preference, indifference, or a weak preference for each criterion when comparing one alternative to another (Seppälä et al., 2001). The two most popular groups of outranking methods are: the elimination and choice translating reality (ELECTRE) methods and the preference ranking organization method for enrichment evaluation (PROMETHEE) methods. The ELECTRE methods classify preferred alternatives and non-preferred 
ones by establishing outranking relationships. To date, the ELECTRE families include ELECTRE I, II, III, and IV as well as some improved ELECTRE methods. The ELECTRE approach uses concordance and discordance indices and threshold values to analyze the outranking relations among the alternatives.

Two very popular methods which have their own mathematical foundations are analytical hierarchy process (AHP) and the technique for order preference by similarity to ideal solution (TOPSIS) method (Vaidya and Kumar, 2006). The basic idea of AHP is to convert subjective assessments of relative importance to a set of overall scores or weights (Vaidya and Kumar, 2006). In AHP, a preferred alternative is selected using pair-wise comparisons of the alternatives based on their relative performance against each criterion. The basis of AHP is that humans are more capable of making relative judgments than absolute judgments. AHP uses a welldefined scale to capture the preferences of the decision maker, and the consistency of preferences can also be checked. AHP is most widely used for weight elicitation of attributes in most of the MADM methods. In comparison, the TOPSIS (Lai et al., 1994) compares a set of alternatives by identifying weights for each dimension, normalizing scores in each dimension, and calculating a distance between the ideal (best on each dimension) and the negative ideal alternatives (worst) across the weighted dimensions based on possible distance measures (e.g., Euclidean distance). Finally, the ratio between the distance (separation) from the negative ideal and the sum distance from the ideal and negative ideal alternatives is used to calculate alternatives.

\subsection{Economic evaluation method (EEM)}

The commonly used EEM is the cost-benefit analysis (CBA) and the cost-effective analysis (CEA). CBA is made to compare the economic feasibility associated with the implementation of different proposals. The main premise of CBA considers that projects should only be commissioned when its benefits exceed the aggregate costs. The CBA is based on the net profit (the difference between benefits and costs) calculation for each one of the available options. The costs involve operation and maintenance costs (O\&MC) and investment cost (IC) adjusted for the time period on which they occur. The total annualized equivalent cost (TAEC), as one of important cost indices, must be calculated by adding the annualized IC to the annual O\&MC (Molinos-Senante et al., 2012a). Not only costs but also the benefits for implementing a treatment facility must be expressed in present value. Therefore, the net benefits must be discounted into present-value terms. By means of a properly chosen discount rate, the investor becomes indifferent regarding cash amounts received at different points of time. The net present value (NPV) of an investment is calculated as a function of the net profit and the discount rate (Aulong et al., 2009). However, some benefits, e.g. environmental quality, are difficult to be valued in monetary. In this situation, costeffectiveness analysis (CEA) is a good choice (Yuan et al., 2010). For the same objectives (quantified in physical terms), CEA can be used to identify an alternative that minimizes actual cost or maximizes output for a certain cost, alternatively (Van Engelen et al., 2008).

\subsection{Data envelopment analysis (DEA)}

In the field of production economics, the term of efficiency denotes the rational use of available resources, which means all production inputs are employed optimally based on the available technology (Hernandez-Sancho et al., 2011). Farrell (1957) pioneered the study of frontier functions as reference points to measure efficiency for each production unit. This was the starting point for the data envelopment analysis (DEA). DEA may handle multiple output/input situations and aggregating performance indices into a single performance index. Basically, the DEA is a mathematical programming method that builds an envelopment surface or efficient production frontier to assess the efficiency of all production units under study or Decision Making Units (DMUs, Charnes et al., 1978). Those DMUs that establish the envelopment surface are considered efficient units (the efficiency index is equal to one), while those not based on the surface are considered inefficient units (the efficiency index is less than one). Likewise, DEA can be used to determine the relative efficiency of each DMU, as long as they are comparable in the sense that they all consume the same inputs (in different quantities) and produce the same set of outputs (in different quantities) (Pastor and Aparicio, 2010). A unit is considered to be efficient if and only if it is not possible to increase its output quantities while its input quantities are fixed, and it is not possible to decrease its input quantities without altering the resulting output quantities (Seiford, 1996). Those efficient units represent best practices serving as reference for evaluating the efficiency of the remaining DMUs. DEA measures the global efficiency for each unit studied. That is, it measures the maximum radial (proportional) reduction in all inputs (increment in all outputs) that would raise the unit's efficiency to the level of the most efficient units (Sueyoshi and Goto, 2011). Most production processes have multiple inputs and outputs, while the radial DEA model does not provide information on the efficiency of specific inputs or outputs (depending on the model's orientation). To solve this problem, Fare et al. (1994) developed a series of non-radial DEA methods where individual input reductions (increase of outputs) are measured. In other words, the non-radial DEA provides an efficiency index for each of the variables in the process. Its great

Table 4

The advantages, disadvantages and applications of the evaluation methods.

\begin{tabular}{|c|c|c|c|}
\hline \multicolumn{2}{|c|}{ Method Advantages } & \multirow{2}{*}{$\begin{array}{l}\text { Disadvantages } \\
\text { It is inadequate to deal with complicated } \\
\text { and economic evaluation problems. }\end{array}$} & \multirow{2}{*}{$\begin{array}{l}\text { Applications } \\
\text { Wang et al., 2012; Benetto et al., 2009; Gallego et al., 2008; Ortiz } \\
\text { et al., 2007; Rodriguez-Garcia et al., 2011. }\end{array}$} \\
\hline LCA & $\begin{array}{l}\text { It is a holistic, long-term and mature evaluation } \\
\text { process, which can attain reliable evaluation } \\
\text { results. }\end{array}$ & & \\
\hline MCDM & $\begin{array}{l}\text { It can simultaneously solve the discrete and } \\
\text { continuous evaluation problems. }\end{array}$ & $\begin{array}{l}\text { It is difficult to calculate the evaluation } \\
\text { result, which may need some special } \\
\text { software. }\end{array}$ & $\begin{array}{l}\text { Demirtas and Üstün, 2008; Huang et al., 2011; Kalbar et al., } \\
\text { 2012a,b. }\end{array}$ \\
\hline EEM & $\begin{array}{l}\text { It can help decision maker attain direct judgment } \\
\text { from the economic aspect. }\end{array}$ & $\begin{array}{l}\text { It only makes evaluation in the economic } \\
\text { aspect, with the technology ignored. }\end{array}$ & $\begin{array}{l}\text { Hernandez-Sancho et al., 2010; Molinos-Senante et al., 2013; } \\
\text { Molinos-Senante et al., 2012b; Zhou et al., } 2010 .\end{array}$ \\
\hline DEA & $\begin{array}{l}\text { It has wide range of application, without the } \\
\text { limitation of dimension and weight. }\end{array}$ & $\begin{array}{l}\text { It need a large number of data, and has the } \\
\text { difficult in forming the effective frontier. }\end{array}$ & $\begin{array}{l}\text { Hernández-Sancho and Sala-Garrido, 2009; Hernandez-Sancho } \\
\text { et al., 2011; Sala-Garrido et al., 2012; Sala-Garrido et al., } 2011.2\end{array}$ \\
\hline FEM & $\begin{array}{l}\text { It has simple model, and can deal with the } \\
\text { multifactorial and uncertain problems. }\end{array}$ & $\begin{array}{l}\text { It has the difficult in forming the } \\
\text { membership function and eliminating } \\
\text { repeated data. }\end{array}$ & $\begin{array}{l}\text { Chen et al., 2010; Chen and Chang, 2007; Karimi et al., 2011; Lu } \\
\text { et al., 2010. }\end{array}$ \\
\hline
\end{tabular}


advantage is the ability to identify the specific inputs on which to act in order to increase the efficiency of the study unit. This method has grown in use with contributions of many studies (Zhou et al., 2007; Zhong et al., 2011; Chen et al., 2011).

\subsection{Fuzzy evaluation method (FEM)}

Decision process for selecting an appropriate alternative usually faces with uncertainties, which may be associated with human judgment regarding relative weights, inadequate information, and evaluation criteria values. The process is also affected by many economic, technological and environmental factors, such as operational maintenance cost, treatment process and pollutants reduction. The conventional evaluation methods are inadequate for dealing with the imprecise or vague information of linguistic assessment (Karimi et al., 2011). Combining fuzzy sets with the conventional evaluation methods, fuzzy evaluation method can overcome the above difficulties and deal with the uncertain information in the real world. The conventional evaluation methods require exact or crisp judgments which the decision maker may be more reluctant to provide than fuzzy ones. Moreover, individual judgments of events are invariably subjective and the interpretations attached to the same words may differ (Zhao et al., 2011). That is why fuzzy sets and fuzzy numbers have been proposed to characterize linguistic variables and to represent the imprecise nature of human judgment (Anagnostopoulos et al., 2007).

Table 4 summarizes the advantages, disadvantages and applications of above all evaluation methods according to the current literatures. Each method has its own characteristics, applicable object and limitations. Therefore, selection of the suitable evaluation methods is so important that it would determine the evaluation result. In practice, the disadvantages of the evaluation method should be avoided and their advantages should be promoted. Different evaluation methods can be coupled to form a better one.

\section{Evaluation indices}

Due to the diversity of rural sanitation tasks and local contexts of engineering, it is impossible to employ a general index to evaluate the environment sanitation system. Many indices can influence the selection of the treatment systems while some of them are so important that they tend to dominate the decision. The selection of Eco-San indices is an important step, which would determine the selection of the Eco-San systems. An Eco-San system means limited usage and degradation of resources through harmful emissions, with the waste export avoided in time or space. An overview of the different indictors could be found in literatures. The evaluation indices of Eco-San could be divided into three classes. Each class of index has many sub-indices, which constitute the evaluation index system.

\subsection{Economic indices}

As one of the first class indices, economic index is often decisive in technology decision in a practical situation (Balkema et al., 2002). Generally, economic index includes several second class indices. Four important economic indices are construction investment costs, operational and maintenance costs, economic benefits and economic feasibility. In detail, the construction processes of each sanitation project need a large amount of money, which could determine the economic feasibility of the project to some extent. The construction investment index is based on the investment required for the system, such as the equipment, pipe installation, the excavation and recovery of road (Molinos-Senante et al., 2013).
Operation and maintenance require resources (time, money and energy) for the system to serve its design life. Therefore, the operation and maintenance indices include the costs of human resources, transportation, electric power and chemicals (MolinosSenante et al., 2012b). Wastewater treatment technologies could bring benefits to environment or society. It is very important to select the suitable sanitation based on the economic benefit index, which involves reuse of wastewater, resource recovery (possibility of nutrient recovery from proposed technology for agricultural use), biogas recovery and electric power recovery (HernandezSancho et al., 2010). To reflect the feasibility of the sanitation, economic feasibility indices were proposed, which include the cost of sewage treatment (CST), net present value (NPV) and payback period (PP) (Hernandez-Sancho et al., 2010; Molinos-Senante et al., 2012b, 2013).

\subsection{Environmental indices}

Although a set of Eco-San indices are different, there seems to be a consensus on the environmental indices. Potential environmental impacts are presented based on the indices of environmental loads, ecosystem quality and resource utilization. The environmental loads index includes risk of pollutants emission to the environment (e.g. nutrients and organic matter), the removal rates of biochemical oxygen demand (BOD), chemical oxygen demand (COD), and total suspended solids (TSS), the depletion of natural resources, and climate change (greenhouse gas emissions and ozone hole). The ecosystem quality indices include aquatic and terrestrial ecotoxicity (ATE), aquatic and terrestrial acidification (ATA), aquatic eutrophication (AE) and land use. The optimal resource utilization index, particularly to address water, nutrients, and energy, includes required land area, land fertility, and biodiversity. The resources index expresses the used amount of non-renewable primary energy related to the fossil energy resources and the additional energy needed for further extraction of minerals considering their progressive depletion. Another group of environmental indices include the quality of effluent and sludge, combined sewer overflows, and gaseous emissions.

\subsection{Social indices}

Both social and cultural indices are difficult to quantify therefore they are often not addressed. However, these indices play an important role in evaluations of the technology implementation. This is especially the cases in water use, sanitation, and small-scale on-site treatment when the end-user is directly involved. The indices in this category could be classified as human health, customers' acceptance, and employment. In detail, the human health index includes carcinogenic, non-carcinogenic, respiratory effects, ionizing radiations effects, stratospheric ozone layer depletion, and exposure to pathogens and fecal matter during toilet use and waste collection. The customers' acceptance index is to evaluate different perceptions of waste and sanitation from people with different cultures. New sanitation concepts, including different toilet systems, may encounter social-cultural difficulties in the implementation. For instance, the reasons to remove these toilets from the houses at an ecological village would include the need to explain to visitors how to use the separation toilet, unhappiness with the proposed technology option from proportion of users, users' accessibility (convenience), reuse centers' accessibility, applicability of direct reuse of on-site toilet products (e.g. Eco-San) to the facilities. The employment index is to evaluate employment opportunities generated by the Eco-San system since the novel sanitation needs much equipment to support the operation. The 


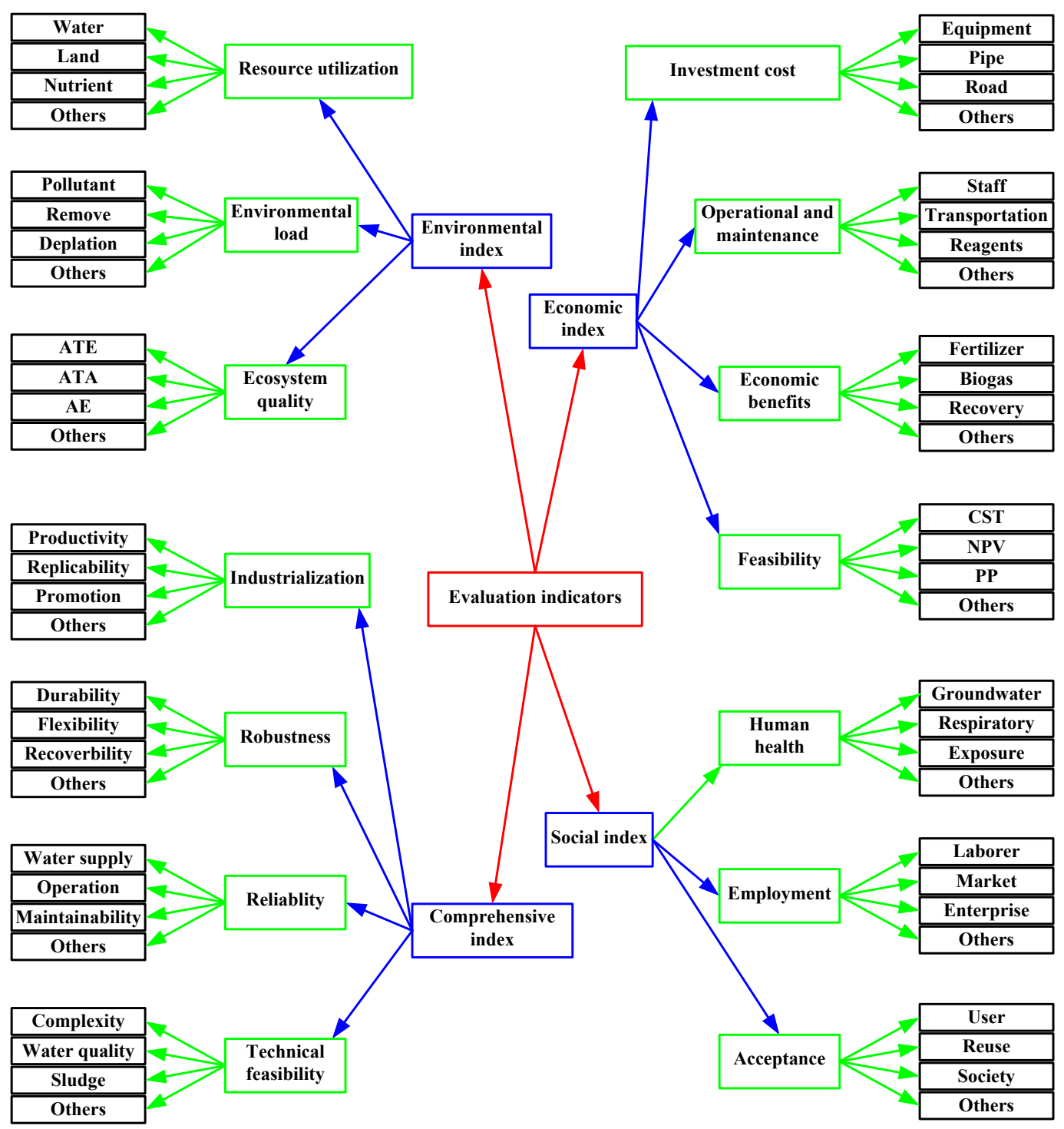

Fig. 8. The components of the evaluation indices.

related market and enterprise also may have the opportunities of growth and development.

\subsection{Comprehensive indices}

Comprehensive indices are also not easy to quantify but described with linguistic terms. These indices can be classified as technical feasibility, reliability, robustness, industrialization and resources consumption. The following indices are used to show the more detailed characteristics of the comprehensive indices. For example, the expertise index is to evaluate the level of expertise for installation and operation of the selected technology. If the expertise is not locally available it may be gained through imports or training. The complexity index is to address ability of beneficiaries to participate in operation and maintenance. The use-ability index is about the easiness to use the proposed facility as viewed by the intended beneficiary community. The institutional requirements index is to quantify if different regulations and control mechanisms that Eco-San systems require fit in the existing institutional infrastructure of the country or region. The policy index is related to government strategies to increase sanitation coverage and service level to the poor people in rural areas. The adoptability index is the ability of the beneficiary to use the technology. The management index is to evaluate the overseeing system that the facility serves its intended purpose. The index of stimulation of Eco-San behavior is to quantify the manners which make Eco-San behavior the most convenient option. These manners include revising technological design and increasing the end-user's awareness, participation, and responsibility. The reliability index is to evaluate water supply reliability, users' operation reliability, system maintainability. The resilience index refers to compatibility of the system with population growth and/or prospective water supply coverage.

Fig. 8 shows the components of the evaluation indices. All these indices should be quantified through measurements, cost calculations, or enquiries. However, in a rapid assessment, many of these indices may be estimated using averages and indications for the influence of a technology on a certain index. For instance, a composting toilet may have a potential advantage for 'stimulation of Eco-San behavior' as no water is used and the end user recycles the compost locally. However, a potential disadvantage may be 'acceptance' because the end user may perceive sanitation without water unhygienic and may not be willing to use the compost in his/her garden. In 
this way, these indices can be used as to-go or not-to-go decision variables in decision making. Many methods can be set in the optimization procedure to only select technologies with potential advantages or to abandon technologies with potential disadvantage.

\section{Results}

The Eco-San systems aim to recover resources from wastewater with the minimized demands on other resources, particularly for water and energy. Therefore, the separate collection and treatment of water flow is not a prerequisite in Eco-San systems, since the centralized and combined flow systems are also possible. The recovery and agricultural use of the organic matters and nutrients contained in sewage would improve soil structure and fertility as well as increase agricultural productivity. The recovery of energy through the anaerobic digestion of feces and organic waste represent a significant step towards energy efficiency (Werner et al., 2009). However, the Eco-San systems are still far from widespread applications due to the following reasons: (a) the costs for employing innovative systems are often higher than those of already established treatment systems; (b) the existing cultural constraints on the usage of treated excreta and sewage have to be overcome by the awareness raising campaigns and capacity building measures for Eco-San; and (c) limited expertise and professionalism on the operation and management of the Eco-San systems hinder the further development of the Eco-San systems.

As no particular technical solution is prescribed, the styles of Eco-San system are very different because of the different combinations of the components. Since every component has its character and suitable area, it is necessary to evaluate these components within the study area in order to obtain suitable combinations. The components, introduced in the review, provide a set of complete alternatives to decision-makers so that optimal decisions can be made quickly and efficiently. With the development of the Eco-San system, many innovative components would be developed to meet the requirement of the rural sewage treatment and result in the appearance of the new Eco-San systems. The costs of some components (e.g. vacuum toilets, vacuum pipes and solid-liquid separators) may decrease as the manufacturing development and mass production, which could improve the dilemma of high costs for introducing the Eco-San systems.

In recent years, a lot of Eco-San projects have been implemented successfully in different rural and sparsely settled urban areas. A great deal of experience has been obtained from the projects, and a number of solutions could be recommended for large-scale applications according to local physical, cultural and socio-economic conditions. It is beneficial to identify the key factors affecting and determining the implementation Eco-San projects, and take some improved measures to promote its development. The evaluation methods in this review have been recommended based on their characteristics, such as theory maturity, wide applications, and simplicity and efficiency of evaluation processes. The project evaluation before its implementation is beneficial to select the suitable components to develop the optimal Eco-San system. The evaluation during the implementation can help the planners adjust the project timely when there are some obstacles and difficulties. The evaluation after the implementation is helpful to verify the feasibility and validity of the project, to summarize experience constantly, and to improve the efficiency of the future Eco-San system.

Although it is very important to select suitable evaluation method for the Eco-San system, the evaluation index is another key factor for the evaluation process, which offers scientifically evaluation basis for the performance evaluation. The setting, selection and quantification of the evaluation index are three critical steps during the evaluation process. The setting of evaluation index helps to obtain a set of candidate indices for preparing the coming evaluation. The selection of evaluation index is useful to determine the key factors in order to reduce the difficulty and complexity of the evaluation. The quantification of evaluation index is to transfer the language terms into the data information so that all available information can be employed. The indices in this review have certain representativeness and practicality, come from the references, real projects and recommendation by experts, and can help decision makers complete the evaluation process easily.

\section{Observations}

In recent years, many successful Eco-San projects have been implemented in rural and sparsely settled urban areas in different countries. Experiences resulting from these projects can be employed to drive the large-scale applications in accordance with local physical, cultural and socio-economic conditions. The Eco-San is also an alternative to solve the problem of resource shortage in the future. Evaluation and selection of suitable components to form an innovative Eco-San system are essential to develop the system according to the environmental, economic and social sustainability. Although the review has introduced many components, evaluation methods and indices, and real cases from references and projects, evaluation and selection of Eco-San system would face many other challenges or limitations. In detail, (a) increasing sustainability of technical systems in society is a major challenge in the near future, which requires a fundamental change regarding our perception to wastewater; (b) the evaluation method should be developed to suit the new evaluation object; (c) the uncertainties, coming from data collection, incomplete information and possible fluctuation, have to be considered during the practical evaluation; (d) the evaluation indices need further investigations, especially, more attention should be paid to the quantitative techniques; (e) the application of organic fertilizers, especially the liquid organic fertilizers, would most likely lead to increased atmospheric emissions of $\mathrm{NH}_{3}$ and the potential acidification of soils and surface waters, which would hinder the development of the Eco-San system; and (f) the substantial TP in gray water could not reach a reasonably low concentration by the natural treatment, which would lead to eutrophication of surface waters. Therefore, more research is required to select suitable Eco-San systems by comprehensive evaluations so that these obstacles can be overcome.

\section{Conclusions}

The review comprehensively summaries the main components of the Eco-San system, typical real cases in different countries, the frequently-used evaluation methods and the framework of evaluation index system. The introduced components can form many different combinations of complete alternatives, which could help decision makers make perfect decisions quickly and efficiently. These typical real projects can guide implementation of construction items and offer many feasible and successful materials for further study. The recommended evaluation methods can help planners make the pre-, interim- and post-evaluations of the project, identify the restriction factors and contributing factors, and take measures to promote the Eco-San development. These indices from references, real projects and experts' recommendation have certain representativeness and practicality, which can help decision makers to complete the evaluation process easily. The review provides the methods for both developing novel Eco-San systems and improving the existing Eco-San systems to solve the wastewater problem in rural areas.

Considering the challenges or limitations existing in the Eco-San research, the recommendations for future research may mainly 
focus on the combination of different components, methods for sustainability assessment, quantification of the evaluation index, and implementation of more real Eco-San cases. The Eco-San systems should be recognized as a new, promising, holistic and sustainable approach to provide safe and decent sanitation, reduce poverty, contribute to food security, preserve our environment, and maintain the natural basis of life. Thus, rural environmental management will gradually change from past treatment to a future resource recycling.

\section{Acknowledgments}

The research was financially supported by the Major Science and Technology Program for Water Pollution Control and Treatment of China (No. 2011ZX07301-003 and No. 2014ZX07204-005) and the National Natural Science Foundation of China (No. 51278484 and No. 51308528). We are deeply grateful to the reviewers and editor for their insightful and careful suggestions, which have greatly helped to improve the quality of manuscript.

\section{References}

Aiyuk, S., Amoako, J., Raskin, L., Van Haandel, A., Verstraete, W., 2004. Removal of carbon and nutrients from domestic wastewater using a low investment, integrated treatment concept. Water Res. 38 (13), 3031-3042.

Al-Jayyousi, O., 2004. Greywater reuse: knowledge management for sustainability. Desalination 167 (15), 27-37.

Anagnostopoulos, K., Gratziou, M., Vavatsikos, A., 2007. Using the fuzzy analytic hierarchy process for selecting wastewater facilities at prefecture level. Eur: Water 19, 15-24.

Anand, C.K., Apul, D.S., 2014. Composting toilets as a sustainable alternative to urban sanitation - a review. Waste Manage. 34 (2), 329-343.

Appels, L., Baeyens, J., Degrève, J., Dewil, R., 2008. Principles and potential of the anaerobic digestion of waste-activated sludge. Prog. Energy Combust. Sci. 34 (6), 755-781.

Aulong, S., Bouzit, M., Dörfliger, N., 2009. Cost-effectiveness analysis of water management measures in two River Basins of Jordan and Lebanon. Water Resour. Manage. 23 (4), 731-753.

Austin, L., Cloete, T., 2008. Safety aspects of handling and using fecal material from urine-diversion toilets - a field investigation. Water Environ. Res. 80 (4), $308-315$.

Avlonitis, S., Kouroumbas, K., Vlachakis, N., 2003. Energy consumption and membrane replacement cost for seawater RO desalination plants. Desalination 157, $151-158$.

Balkema, A.J., Preisig, H.A., Otterpohl, R., Lambert, F.J., 2002. Indexes for the sustainability assessment of wastewater treatment systems. Urban Water 4 (2), 153-161.

Basakcilardan-Kabakci, S., Ipekoglu, A.N., Talinli, I., 2007. Recovery of ammonia from human urine by stripping and absorption. Environ. Eng. Sci. 24 (5), 615-624.

Bassett, H., Bedwell, W.L., 1933. 210. Studies of phosphates. Part I. Ammonium magnesium phosphate and related compounds. Q. J. Chem. Soc. 854-871.

Bdour, A.N., Hamdi, M.R., Tarawneh, Z., 2009. Perspectives on sustainable wastewater treatment technologies and reuse options in the urban areas of the Mediterranean region. Desalination 237 (1-3), 162-174.

Benetto, E., Nguyen, D., Lohmann, T., Schmitt, B., Schosseler, P., 2009. Life cycle assessment of ecological sanitation system for small-scale wastewater treatment. Sci. Total Environ. 407 (5), 1506-1516.

Berger, W., 2009. Technology review of composting toilets, list of manufacturers and commercially available composting toilets. http://www.susana.org/docs ccbk/susana_download/2-876-gtz2009-technology-review-compostingtoiletsappendix.pdf.

Brissaud, F., 2007. Low technology systems for wastewater treatment: perspectives. Water Sci. Technol. 55 (7), 1-9.

Charnes, A., Cooper, W.W., Rhodes, E., 1978. Measuring the efficiency of decision making units. Eur. J. Oper. Res. 2 (6), 429-444.

Chen, J.C., Chang, N.B., 2007. Mining the fuzzy control rules of aeration in a submerged biofilm wastewater treatment process. Eng. Appl. Artif. Intell. 20 (7), 959-969.

Chen, Y., Cheng, J.J., Creamer, K.S., 2008. Inhibition of anaerobic digestion process: a review. Bioresour. Technol. 99 (10), 4044-4064.

Chen, G.R., Shi, J.L., Deng, J.L., Lei, L., Xiong, Q., Ieee, 2010. An industrial wastewate pollution degree evaluation method based on improved fuzzy evaluation theories. In: 8th World Congress on Intelligent Control and Automation. Jun 06-09, pp. $1662-1667$.

Chen, J.-X., Deng, M., Gingras, S., 2011. A modified super-efficiency measure based on simultaneous input-output projection in data envelopment analysis. Comput. Oper. Res. 38 (2), 496-504.
China Health Statistical Yearbooks, 1999-2012. National Health and Family Planning Commission of the People's Republic of China, Beijing (in Chinese).

Demirtas, E.A., Üstün, Ö., 2008. An integrated multiobjective decision making process for supplier selection and order allocation. Omega 36 (1), 76-90.

Eriksson, E., Andersen, H.R., Madsen, T.S., Ledin, A., 2009. Greywater pollution variability and loadings. Ecol. Eng. 35 (5), 661-669.

Escher, B.I., Bramaz, N., Maurer, M., Richter, M., Sutter, D., von Känel, C., Zschokke, M., 2005. Screening test battery for pharmaceuticals in urine and wastewater. Environ. Toxicol. Chem. 24 (3), 750-758.

Esrey, S.A., Gouch, J., Rapaport, D., Sawyer, R., Simpson-H'ebert, M., Vargas, J., 1998. Ecological Sanitation. Swedish International Development Cooperation Agency (SIDA), Stockholm, Sweden.

Fan, B., 2011. Low-cost decentralized sanitation system based on vacuum collection and reuse of excreta and kitchen waste. http://forum.susana.org/forum/ categories/98-resource-recovery-from-excreta-or-faecal-sludge/4949-lowcost-decentralized-sanitation-system-based-on-vacuum-collection-and-reuseof-excreta-and-kitchen-waste-chinese-academy-of-sciences-china.

Fare, R., Grosskopf, S., Lovell, C.K., 1994. Production Frontiers. Cambridge University Press.

Farrell, M.J., 1957. The measurement of productive efficiency. J. R. Stat. Soc. Ser. A Gen. 120 (3), 253-290.

Gallego, A., Hospido, A., Moreira, M.T., Feijoo, G., 2008. Environmental performance of wastewater treatment plants for small populations. Resour. Conserv. Recycl. 52 (6), 931-940.

Gaskin, J., Steiner, C., Harris, K., Das, K., Bibens, B., 2008. Effect of low-temperature pyrolysis conditions on biochar for agricultural use. Trans. ASABE 51 (6), 2061-2069.

Gaunt, J.L., Lehmann, J., 2008. Energy balance and emissions associated with biochar sequestration and pyrolysis bioenergy production. Environ. Sci. Technol. 42 (11), 4152-4158.

GIZ, 2012. Worldwide List of 324 Documented Ecosan Projects by Various Organizations. Gesellschaft für Internationale Zusammenarbeit (GIZ) GmbH, Eschborn, Germany. http://www.susana.org/en/resources/library/details/1423.

Guzha, E., Nhapi, I., Rockstrom, J., 2005. An assessment of the effect of human faeces and urine on maize production and water productivity. Phys. Chem. Earth - A/ B/C 30 (11-16), 840-845.

Haq, G., Cambridge, H., 2012. Exploiting the co-benefits of ecological sanitation. Curr. Opin. Environ. Sustain. 4 (4), 431-435.

Harada, H., Shimizu, Y., Miyagoshi, Y., Matsui, S., Matsuda, T., Nagasaka, T., 2006. Predicting struvite formation for phosphorus recovery from human urine using an equilibrium model. Water Sci. Technol. 54 (8), 247-255.

Hellström, D., Johansson, E., Grennberg, K., 1999. Storage of human urine: acidification as a method to inhibit decomposition of urea. Ecol. Eng. 12, 253-269.

Hernández-Sancho, F., Sala-Garrido, R., 2009. Technical efficiency and cost analysis in wastewater treatment processes: a DEA approach. Desalination 249, 230-234.

Hernandez-Sancho, F., Molinos-Senante, M., Sala-Garrido, R., 2010. Economic valuation of environmental benefits from wastewater treatment processes: an empirical approach for Spain. Sci. Total Environ. 408 (4), 953-957.

Hernandez-Sancho, F., Molinos-Senante, M., Sala-Garrido, R., 2011. Energy efficiency in Spanish wastewater treatment plants: a non-radial DEA approach. Sci. Total Environ. 409, 2693-2699.

Hou, J.W., Qu, B., Li, X.L., Fan, B., 2012. The utilization situation of rural biogas and its significance on rural domestic wastewater treatment: example of Hebei and Shandong Province. China Biogas 30 (1), 47-51.

Howard, A.F., 1991. A critical look at multiple criteria decision making techniques with reference to forestry applications. Can. J. For. Res. 21, 1649-1659.

Huang, I.B., Keisler, J., Linkov, I., 2011. Multi-criteria decision analysis in environmental sciences: ten years of applications and trends. Sci. Total Environ. 409, 3578-3594.

Huber, G.P., 1974. Multi-attribute utility models: a review of field and field-like studies. Manage. Sci. 20, 1393-1402.

Iglesias, L., Laca, A., Herrero, M., Díaz, M., 2012. A life cycle assessment comparison between centralized and decentralized biodiesel production from raw sunflower oil and waste cooking oils. J. Clean. Prod. 37, 162-171.

IWA, 2007. IWA Specialist Group "Resources Oriented Sanitation". http://www. ecosan.org/.

Jfnsson, H., 2001. Source separation of human urine-separation efficiency and effects on water emissions, crop yield, energy usage and reliability. In: First International Conference on Ecological Sanitation, Nanning, PR China, 5 (8), pp. $39-45$.

Jha, A.K., Li, J., Nies, L., Zhang, L., 2011. Research advances in dry anaerobic digestion process of solid organic wastes. Afr. J. Biotechnol. 10 (65), 14242-14253.

Johnston, A., Richards, I., 2003. Effectiveness of different precipitated phosphates as phosphorus sources for plants. Soil Use Manage. 19 (1), 45-49.

Kalbar, P.P., Karmakar, S., Asolekar, S.R., 2012a. Selection of an appropriate wastewater treatment technology: a scenario-based multiple-attribute decisionmaking approach. J. Environ. Manage. 113, 158-169.

Kalbar, P.P., Karmakar, S., Asolekar, S.R., 2012b. Technology assessment for wastewater treatment using multiple-attribute decision-making. Technol. Soc. 34 (4), 295-302.

Karak, T., Bhattacharyya, P., 2011. Human urine as a source of alternative natural fertilizer in agriculture: a flight of fancy or an achievable reality. Resour. Conserv. Recycl. 55, 400-408.

Karimi, A.R., Mehrdadi, N., Hashemian, S.J., Bidhendi, G.R.N., Moghaddam, R.T., 2011. Selection of wastewater treatment process based on the analytical hierarchy 
process and fuzzy analytical hierarchy process methods. Int. J. Environ. Sci. Technol. 8, 267-280.

Keeney, R.L., 1975. Energy Policy and Value Tradeoffs. IIASA.

Kocatürk, N.P., Baykal, B.B., 2012. Recovery of plant nutrients from dilute solutions of human urine and preliminary investigations on pot trials. Clean - Soil Air Water 40 (5), 538-544.

Kujawa-Roeleveld, K., Fernandes, T., Wiryawan, Y., Tawfik, A., Visser, M., Zeeman, G., 2005. Performance of UASB septic tank for treatment of concentrated black water within DESAR concept. Water Sci. Technol. 52 (1-2), 307-313.

Lai, Y.-J., Liu, T.-Y., Hwang, C.-L., 1994. Topsis for MODM. Eur. J. Oper. Res. 76 (3), $486-500$.

Langergraber, G., Muellegger, E., 2005. Ecological sanitation-a way to solve global sanitation problems? Environ. Int. 31, 433-444.

Le Corre, K., Valsami-Jones, E., Hobbs, P., Parsons, S., 2009. Phosphorus recovery from wastewater by struvite crystallization: a review. Crit. Rev. Env. Sci. Technol. 39, 433-477.

Lehtoranta, S., Vilpas, R., Mattila, T.J., 2014. Comparison of carbon footprints and eutrophication impacts of rural on-site wastewater treatment plants in Finland. J. Clean. Prod. 65, 439-446.

Li, F., Wichmann, K., Otterpohl, R., 2009. Review of the technological approaches for grey water treatment and reuses. Sci. Total Environ. 407, 3439-3449.

Lienert, J., Larsen, T.A., 2009. High acceptance of urine source separation in seven European countries: a review. Environ. Sci. Technol. 44, 556-566.

Lu, X.W., Li, L.Y., Lei, K., Wang, L.J., Zhai, Y.X., Zhai, M., 2010. Water quality assessment of Wei River, China using fuzzy synthetic evaluation. Environ. Earth Sci. 60 (8), 1693-1699.

Magri, M.E., Philippi, L.S., Vinneras, B., 2013. Inactivation of pathogens in feces by desiccation and urea treatment for application in urine-diverting dry toilets. Appl. Environ. Microbiol. 79, 2156-2163.

Malekpour, S., Langeveld, J., Letema, S., Clemens, F., van Lier, J.B., 2013. Judgment under uncertainty; a probabilistic evaluation framework for decision-making about sanitation systems in low-income countries. J. Environ. Manage. 118, 106-114.

Malisie, A.F., 2007. The potential of nutrient reuse from a source-separated domestic wastewater system in Indonesia - case study: ecological sanitation pilot plant in Surabaya. Water Sci. Technol. 56 (5), 141-148.

Mao, C.L., Feng, Y.Z., Wang, X.J., Ren, G.X., 2015. Review on research achievements of biogas from anaerobic digestion. Renew. Sustain. Energy Rev. 45, 540-555.

Martens, W., Böhm, R., 2009. Overview of the ability of different treatment methods for liquid and solid manure to inactivate pathogens. Bioresour. Technol. 100 (22), 5374-5378.

Maurer, M., Pronk, W., Larsen, T.A., 2006. Treatment processes for source-separated urine. Water Res. 40, 3151-3166.

Metcalf, L., Eddy, H.P., Tchobanoglous, G., 1972. Wastewater Engineering: Treatment, Disposal, and Reuse. McGraw-Hill.

Mo, W.W., Zhang, Q., 2013. Energy-nutrients-water nexus: integrated resource recovery in municipal wastewater treatment plants. J. Environ. Manage. 127, $255-267$.

Molinos-Senante, M., Garrido-Baserba, M., Reif, R., Hernández-Sancho, F., Poch, M., 2012a. Assessment of wastewater treatment plant design for small communities: environmental and economic aspects. Sci. Total Environ. 427-428, $11-18$.

Molinos-Senante, M., Hernandez-Sancho, F., Sala-Garrido, R., 2012b. Economic feasibility study for new technological alternatives in wastewater treatment processes: a review. Water Sci. Technol. 65.

Molinos-Senante, M., Hernández-Sancho, F., Sala-Garrido, R., Cirelli, G., 2013. Economic feasibility study for intensive and extensive wastewater treatment considering greenhouse gases emissions. J. Environ. Manage. 123, 98-104.

Montangero, A., Le, C., Nguyen, V.A., Vu, D.T., Pham, T.N., Belevi, H., 2007. Optimising water and phosphorus management in the urban environmental sanitation system of Hanoi, Vietnam. Sci. Total Environ. 384, 55-66.

Müller, C., 2007. Anaerobic Digestion of Biodegradable Solid Waste in Low- and Middle-income Countries. Sandec Report.

Münch, E.v., 2008. Overview of Anaerobic Treatment Options for Sustainable Sanitation Systems. Coupling Sustainable Sanitation and Groundwater Protection, pp. 14-17.

Niwagaba, C., Kulabako, R.N., Mugala, P., Jonsson, H., 2009a. Comparing microbial die-off in separately collected faeces with ash and sawdust additives. Waste Manage. 29, 2214-2219.

Niwagaba, C., Nalubega, M., Vinnerås, B., Sundberg, C., Jönsson, H., 2009b. Substrate composition and moisture in composting source-separated human faeces and food waste. Environ. Technol. 30, 487-497.

Niwagaba, C., Nalubega, M., Vinneras, B., Sundberg, C., Jonsson, H., 2009c. Benchscale composting of source-separated human faeces for sanitation. Waste Manage. 29 (2), 585-589.

Ortiz, M., Raluy, R.G., Serra, L., 2007. Life cycle assessment of water treatment technologies: wastewater and water-reuse in a small town. Desalination 204, $121-131$.

Otterpohl, R., Braun, U., Oldenburg, M., 2004. Innovative technologies for decentralised water-, wastewater and biowaste management in urban and peri-urban areas. Water Sci. Technol. 48, 23-32.

Panuvatvanich, A., Koottatep, T., Kone, D., 2009. Influence of sand layer depth and percolate impounding regime on nitrogen transformation in verticalflow constructed wetlands treating faecal sludge. Water Res. 43, 2623-2630.
Paraknowitsch, J.P., Thomas, A., Antonietti, M., 2009. Carbon colloids prepared by hydrothermal carbonization as efficient fuel for indirect carbon fuel cells. Chem. Mater. 21, 1170-1172.

Pasqualino, J.C., Meneses, M., Abella, M., Castells, F., 2009. LCA as a decision support tool for the environmental improvement of the operation of a municipal wastewater treatment plant. Environ. Sci. Technol. 43, 3300-3307.

Pastor, J.T., Aparicio, J., 2010. The relevance of DEA benchmarking information and the Least-Distance Measure. Comment Math. Comput. Modell. 52, 397-399.

Pathak, B., 1999. Sanitation is the key to healthy cities - a profile of Sulabh International. Environ. Urban. 11, 221-230.

Paulo, P.L., Azevedo, C., Begosso, L., Galbiati, A.F., Boncz, M.A., 2013. Natural systems treating greywater and blackwater on-site: integrating treatment, reuse and landscaping. Ecol. Eng. 50 (4), 95-100.

Prüss, A., Kay, D., Fewtrell, L., Bartram, J., 2002. Estimating the burden of disease from water, sanitation, and hygiene at a global level. Environ. Health Perspect. 110, 537-542.

Rauch, T., Drewes, J.E., 2005. Quantifying biological organic carbon removal in groundwater recharge systems. J. Environ. Eng. 131, 909-923.

Reinvent the Toilet Challenge: China, 2013. Gates-foundation. http://www. gatesfoundation.org/.

Remy, C., 2010. Life Cycle Assessment of Conventional and Source-separation Systems for Urban Wastewater Management (Ph.D. thesis). Department of Water Quality Control, Technische Universität Berlin, Berlin, Germany. http://opus. kobv.de/tuberlin/volltexte/2010/2543/pdf/remy_christian.pdf.

Ridderstolpe, P., 2007. Mulch Filter and Resorption Trench for Onsite Greywater Management. Report for a Demo Facility Built in Kimberley, South Africa. EcoSanRes Programme, Stockholm Environment Institute, Stockholm, Sweden.

Rodriguez-Garcia, G., Molinos-Senante, M., Hospido, A., Hernández-Sancho, F. Moreira, M.T., Feijoo, G., 2011. Environmental and economic profile of six typologies of wastewater treatment plants. Water Res. 45, 5997-6010.

Sala-Garrido, R., Molinos-Senante, M., Hernández-Sancho, F., 2011. Comparing the efficiency of wastewater treatment technologies through a DEA metafrontier model. Chem. Eng. J. 173 (3), 766-772.

Sala-Garrido, R., Hernandez-Sancho, F., Molinos-Senante, M., 2012. Assessing the efficiency of wastewater treatment plants in an uncertain context: a DEA with tolerances approach. Environ. Sci. Policy 18, 34-44.

Schouten, M., Mathenge, R., 2010. Communal sanitation alternatives for slums: a case study of Kibera, Kenya. Phys. Chem. Earth - A/B/C 35, 815-822.

Seiford, L.M., 1996. Data envelopment analysis: the evolution of the state of the art (1978-1995). J. Prod. Anal. 7, 99-137.

Seppälä, J., Basson, L., Norris, G.A., 2001. Decision analysis frameworks for life-cycle impact assessment. J. Ind. Ecol. 5, 45-68.

Steinbeiss, S., Gleixner, G., Antonietti, M., 2009. Effect of biochar amendment on soil carbon balance and soil microbial activity. Soil Biol. Biochem. 41, 1301-1310.

Sueyoshi, T., Goto, M., 2011. DEA approach for unified efficiency measurement: assessment of Japanese fossil fuel power generation. Energy Econ. 33, 292-303.

Thibodeau, C., Monette, F., Bulle, C., Glaus, M., 2014. Comparison of black water source-separation and conventional sanitation systems using life cycle assessment. J. Clean. Prod. 67, 45-57.

Tilley, E., Ulrich, L., Lüthi, C., Reymond, Ph., Zurbrügg, C., 2014. Compendium of Sanitation Systems and Technologies, 2nd Revised Edition. Swiss Federal Institute of Aquatic Science and Technology (Eawag), Duebendorf, Switzerland. http://www.susana.org/en/resources/library/details/454.

Titirici, M.M., Thomas, A., Yu, S.-H., Müller, J.-O., Antonietti, M., 2007. A direct synthesis of mesoporous carbons with bicontinuous pore morphology from crude plant material by hydrothermal carbonization. Chem. Mater. 19, 4205-4212.

Udert, K.M., Larsen, T.A., Gujer, W., 2003. Estimating the precipitation potential in urine-collecting systems. Water Res. 37, 2667-2677.

Udert, K., Larsen, T., Gujer, W., 2006. Fate of major compounds in source-separated urine. Water Sci. Technol. 54, 413-420.

Vaidya, O.S., Kumar, S., 2006. Analytic hierarchy process: an overview of applications. Eur. J. Oper. Res. 169, 1-29.

Van Engelen, D., Seidelin, C., Van der Veeren, R., Barton, D.N., Queb, K., 2008. Costeffectiveness analysis for the implementation of the EU Water Framework Directive. Water Policy 10 (3), 207-220.

Vinneras, B., 2007. Comparison of composting, storage and urea treatment for sanitising of faecal matter and manure. Bioresour. Technol. 98, 3317-3321.

von Munch, E., Mayumbelo, K.M.K., 2007. Methodology to compare costs of sanitation options for low-income peri-urban areas in Lusaka, Zambia. Water SA 33, 593-602.

Vymazal, J., 2005. Horizontal sub-surface flow and hybrid constructed wetlands systems for wastewater treatment. Ecol. Eng. 25, 478-490.

Wang, X., Liu, J., Ren, N.-Q., Duan, Z., 2012. Environmental profile of typical anaerobic/anoxic/oxic wastewater treatment systems meeting increasingly stringent treatment standards from a life cycle perspective. Bioresour. Technol. 126, 31-40.

Werner, C., Panesar, A., Rud, S.B., Olt, C.U., 2009. Ecological sanitation: principles technologies and project examples for sustainable wastewater and excreta management. Desalination 248, 392-401.

Wilsenach, J., Van Loosdrecht, M., 2003. Impact of separate urine collection on wastewater treatment systems. Water Sci. Technol. 48, 103-110.

Wilsenach, J.A., Schuurbiers, C.A., van Loosdrecht, M.C., 2007. Phosphate and potassium recovery from source separated urine through struvite precipitation. Water Res. 41, 458-466. 
Winblad, U., 2004. Development of eco-san systems. In: Ecosan-Closing the Loop in Wastewater Management and Sanitation, Proceedings of International Symposium, Sweden, pp. 58-62.

Winblad, U., Simpson-Hébert, M., Calvert, P., Morgen, P., Rosemarin, A., Sawyer, R. Xiao, J., 2004. Ecological Sanitation-Revised and Enlarged Edition. Stockholm Environment Institute.

Winker, M., Vinnerăs, B., Muskolus, A., Arnold, U., Clemens, J., 2009. Fertiliser products from new sanitation systems: their potential values and risks. Bioresour. Technol. 100, 4090-4096.

Yuan, Z., Jiang, W., Bi, J., 2010. Cost-effectiveness of two operational models at industrial wastewater treatment plants in China: a case study in Shengze town, Suzhou City. J. Environ. Manage. 91, 2038-2044.

Zanakis, S.H., Solomon, A., Wishart, N., Dublish, S., 1998. Multi-attribute decision making: a simulation comparison of select methods. Eur. J. Oper. Res. 107, 507-529.

Zhang, D., Gersberg, R.M., Keat, T.S., 2009. Constructed wetlands in China. Ecol. Eng. $35,1367-1378$
Zhang, T., Xu, D., He, F., Zhang, Y., Wu, Z., 2012. Application of constructed wetland for water pollution control in China during 1990-2010. Ecol. Eng. 47, 189-197.

Zhao, X., Shen, Z., Xiong, M., Qi, J., 2011. Key uncertainty sources analysis of water quality model using the first order error method. Int. J. Environ. Sci. Technol. 8, 137-148.

Zhong, W., Yuan, W., Li, S.X., Huang, Z., 2011. The performance evaluation of regional R\&D investments in China: an application of DEA based on the first official China economic census data. Omega 39, 447-455.

Zhou, P., Ang, B., Poh, K., 2006. Decision analysis in energy and environmental modeling: an update. Energy 31, 2604-2622.

Zhou, P., Poh, K.L., Ang, B.W., 2007. A non-radial DEA approach to measuring environmental performance. Eur. J. Oper. Res. 178, 1-9.

Zhou, C.B., Liu, J.R., Wang, R.S., Yang, W.R., Jin, J.S., 2010. Ecological-economic assessment of ecological sanitation development in the cities of Chinese Loess Plateau. Ecol. Complex. 7 (2), 162-169. 